\title{
Grundtvig-litteratur 1979-1983
}

\section{Ved Aage Jorgensen}

Nedenstående bibliografi over Grundtvig-litteratur 1979-1983 er at betragte som en videreførelse af tilsvarende bibliografier offentliggjort i Grundtvig-Studier 1968, 1971, 1974 og 1979. At den i omfang nærmer sig, hvad forgængerne fylder tilsammen, skyldes i meget høj grad publikationsaktiviteten i forbindelse med Grundtvigs 200-års fødselsdag i 1983.

Stoffet er ordnet efter bibliografiske kriterier frem for efter emnekredse. Tidsrammen gælder ikke absolut, idet enkelte bidrag af ældre dato og adskillige fra begyndelsen af 1984 er medtaget; manuskriptet afleveredes til redaktionen pr. 1.6. 1984.

Med hensyn til avisstof (artikler fortegnet ndf. u. V, samt anmeldelser fortegnet sammen med de arbejder, de knytter sig til) gælder, at bibliografien ikke gør krav på fuldstændighed. Medtaget er i alt væsentligt, hvad også Dansk artikelindeks og Dansk anmeldelsesindeks har fundet det rimeligt at redde fra glemsel.

Dog er der, forsåvidt angår månederne august og september 1983 , foretaget en systematisk gennemgang af 44 danske dagblade med henblik på registrering af "fødselsdagsstof" (med påfølgende frasortering af reportageartikler, small-talk, etc.). Jeg skylder Mogens Wiederholt tak, fordi han påtog sig dette arbejde, - og jeg skylder N. F. S. Grundtvigs Fond tak for en bevilling til honorering af det.

En opfordring indlagt i 1983-årgangen af Grundtvig-Studier til læserne om at række mig en hjælpende hånd fremkaldte desværre kun en halv snes reaktioner. Større beredvillighed har jeg mødt ved direkte henvendelse til skribenter, forlag og organisationer. F. eks. har Brigitte Nøsted, Det danske Selskab, forsynet mig med adskillige værdifulde oplysninger.

Som venteligt markeredes 200 -års fødselsdagen i en række højskoleårsskrifter. Højskolernes Sekretariat har hjulpet mig med at finde dette stof frem. 


\section{Udgaver}

Danne-Virke, et Tids-Skrift. I-II. AKA-print, Højbjerg 1983. xvi, 392; xii, 379 s. [Fotografisk optryk af tidsskriftets to første årgange, 1816-17.]

Anmeldt af: Johs. H. Christensen (Kristeligt Dagblad 15.8. 1983), Jørgen Gleerup (Fyens Stiftstidende 13.9. 1983), P.G. Lindhardt (Jyllands-Posten 15.8. 1983), Kaj Thaning (Højskolebladet 1983, s. 679-80), Niels Thomsen (Prasteforeningens Blad LXXIV 1984, s. 347-48).

Danske salmer. Sthen, Kingo, Brorson, Grundtvig, Ingemann. Udgivet med efterskrift af Erling Nielsen. 3. oplag. Gyldendal, København 1981. 251 s. (Gyldendals Bibliotek/ Dansk Litteratur, 48.) [Heri Grundtvig-salmer s. 128-201, efterskrift s. 229-46.] [1. oplag, 1965.]

Danske salmer $i$ tysk oversattelse. (Dänische Kirchenlieder in deutscher Übersetzung). Udgivet af $\mathrm{H}$. Hejselbjerg Paulsen og Poul Aaholm. Oversættelser af Andreas Øster. Skandia Verlag, Flensburg 1983. 77 s. [H. Hejselbjerg Paulsen, "Tvesprogede salmebøger i Danmark ", s. 9-13; 10 salmer af Brorson, 38 af Grundtvig, 5 af Kingo.]

Dejlig er den Himmel blaa. Udvalgte digte ved Steen Johansen. Gyldendal, København 1983. 180 s. [Fotografisk optryk af: Udvalgte Digte. Med indledning (s. 5-7) og noter (s. 162-77) af Steen Johansen. Hans Reitzel, København 1963. 180 s.] [Også i Lyrikbogklubben Borgen-Gyldendal.]

Anmeldt af: T[orben] B[rostrøm] (Information 22.12. 1983).

5 Jule-Psalmer. Illustreret med tegninger af Herluf Jensenius. Introduktion af Ebbe Kløvedal Reich. Stig Vendelkær, København 1983. $45 \mathrm{~s}$.

Folkets Genmale. Grundtvigs skelsættende oprørsskrift Kirkens Genmæle og fire artikler om Grundtvigs kirkelige anskuelse i vor tid af Poul Engberg, Karen Marie Mortensen, Mogens Lindhardt og Helge Noe-Nygaard. Samleren, København 1983. 158 s. [Indhold: "Kirkens Gienmæle imod Professor Theologiæ Dr. H. N. Clausen ", s. 11-51; Poul Engberg, "Den grundtvigske reformation. Bidrag til 'Kirkens Genmæle's historie", s. 52-88; Helge Noe-Nygaard, "Skal den grundtvigske reformation fortsættes?", s. 89-108; Mogens Lindhardt, "Nutidige udfordringer til den kirkelige anskuelse", s. 109-30; Karen Marie Mortensen, "Folkets genmæle", s. 131-58.]

Anmeldt af: Hans Bagge (Dagbladet 11.6. 1983), Peter Fischer-Møller (Fønix VII 1983, s. 286-88), Jørgen Gleerup (Morgenposten 3.7. 1983), Ketty Jensen (Folkebladet Sydjylland 23.7. 1983), Arne G. Larsen (Vestkysten 23.7. 1983), P. G. Lindhardt (JyllandsPosten 25.7. 1983), Mogens Müller (Kristeligt Dagblad 23.6. 1983), Johannes Værge (Weekendavisen 9.12. 1983), anon. (Flensborg Avis 11.7. 1983).

Grundtvig. Tekstudvalg ved K. E. Bugge. Nyt Nordisk Forlag, København 1980. 124 s. [Indledning s. 9-24; tekstudvalg, omfattende afsnittene "Teologi, kirke og kristenliv", "Menneskeligt og kristeligt" og "Pædagogik, skole og undervisning", s. 26-114; oplysninger s. 115-24.]

Anmeldt af: Johs. H. Christensen (Fønix IV 1980, s. 155-58), Søren Lodberg Hvas (Kristeligt Dagblad 15.3. 1980), Aage Jørgensen (Grundtvig-Studier 1981, s. 84), Vilhelm Nielsen (Hojskolebladet 1980, s. 230-31).

A Grundtvig Anthology. Selections from the Writings of N. F. S. Grundtvig (1783-1872). Edited, annotated and introduced by Niels Lyhne Jensen, William Michelsen, Gustav 
Albeck, Hellmut Toftdahl and Chr. Thodberg. Translated by Edward Broadbridge and Niels Lyhne Jensen. General editor: Niels Lyhne Jensen. James Clarke \& Co., Cambridge/Centrum, Viby J. 1984. 195 s. [Indledning af NLJ s. 13-30; forbemærkninger til de enkelte afsnit af WM s. 33-34 og 65, af GA s. 87-89, af HT s. 127-28, af CT s. 163-64 og af NLJ s. 185-87.]

Grundtvig og grundtvigianerne. Indføring og kilder. Udgivet af Knud Munck. Åløkke, Horsens 1984.94 s. [Indledning s. 7-26, kilder s. 27-79 (12 tekster af Grundtvig, 18 af andre).]

Anmeldt af: K.E. Bugge (Højskolebladet 1984, s. 397 [med rettelse s. 445]), Erik H. Madsen (Gymnasieskolen LXVII 1984, s. 435-36), Christian Ulrich Terp (Dansk Kirketidende CXXXVI 1984, s. 130-31).

Grundtvigs Erindringer og Erindringer om Grundtvig. I Udvalg ved Steen Johansen og Henning Høirup. 2. oplag. C. A. Reitzel, København 1983. 303 s. [Fotografisk optryk af 1. oplag, 1948.]

Anmeldt af: Jørgen Gleerup (Fyens Stiftstidende 9.2. 1983), Mogens Müller (Kristeligt Dagblad 14.2. 1983), Jørgen Pedersen (Fønix VII 1983, s. 148-50).

Grundtvigs fodselsdagsgave til det danske folk. Udvalgt af Ejvind Larsen og med forord af Ebbe Kløvedal Reich. Vindrose, København 1983. 276 s.

Anmeldt af: Jørgen Gleerup (Fyens Stiftstidende 20.9. 1983), Carsten Jensen (Information 8.9. 1983), P. G. Lindhardt (Jyllands-Posten 20.9. 1983), Ebbe Kløvedal Reich (B.T. 8.9. 1983), Bent Windfeld (Kristeligt Dagblad 22.9. 1983).

Historie og kristendom. En Grundtvig-antologi. Forlaget i Haarby, Hårby 1983. 237 s. [Forord s. 7-10.]

Anmeldt af: Jørgen Gleerup (Fyens Stiftstidende 7.10. 1983), Doris Ottesen (Kristeligt Dagblad 21.10. 1983).

Kirchenlieder von N. F. S. Grundtvig. Auszug aus dem Gesangbuch der dänischen Volkskirche "Den danske Salmebog" in deutscher Sprache herausgegeben von einer "Grundtvig-Werkstatt" in Südschleswig anlässlich des 200. Geburtstages von Grundtvig am 8. September 1983. [Redaktion: Jørgen Kristensen.] Det danske Selskab, København 1983. 77 s. [Indhold: 52 salmer.]

Anmeldt af: G. F. W. Herngreen (Hymnologiske Meddelelser XIII 1984, s. 37-49), Mogens Müller (Kristeligt Dagblad 10.10. 1983), Bent Noack (Prosteforeningens Blad LXXIII 1983, s. 809-14; rettelse hertil s. 857), Ingrid Oberborbeck/Svend Andersen (Flensborg Avis 16.12. 1983).

Nordens Mythologi. Fotografisk optryk af 3. udgave fra 1870. Forord af Poul Engberg. Samleren, København 1983. xvi, XXIV, 586 s.

Anmeldt af: Jens Brun (Højskolebladet 1983, s. 732-33), Jørgen Gleerup (Fyens Stiftstidende 18.8. 1983), Erik H. Madsen (Vestkysten 11.8. 1983), Mogens Müller (Kristeligt Dagblad 4.8. 1983), Flemming Chr. Nielsen (Jyllands-Posten 26.8. 1983), K. P. (Sjallands Tidende 4.10. 1983), Poul Wolff (Aarhuus Stiftstidende 6.8. 1983).

Om Mennesket $i$ Verden. Udgivet i 200 -året for Grundtvigs fødsel og forsynet med indledning [s. 7-24] og noter [s. 73-77] ved K. B. Gjesing. Poul Kristensen, Herning 1983. 77 s. [Oprindelig offentliggjort i Danne-Virke, 1817.]

Anmeldt af: Jørgen Gleerup (Fyens Stiftstidende 27.9. 1983), P. G. Lindhardt (JyllandsPosten 11.10. 1983), Doris Ottesen (Kristeligt Dagblad 12.4. 1984).

N. F. S. Grundtvigs Prodikener 1822-26 og 1832-39. I-XII. Udgivet af Christian Thodberg.

G. E. C. Gad, København 1983- . [Følgende bind udkom i 1983: I: 1822-23, 438 s. 
("Fortale til udgaven" s. 9-27, indledning s. 28-50); II: 1823-24, 399 s. (indledning s. 722); III: 1824-25, 285 s. (indledning s. 7-22); IV: 1825-26 med tillag 1826-30, 193 s. (indledning s. 7-21).]

Anmeldt af: Poul Borum (Ekstra-Bladet 25.3. 1983), Palle Dinesen (Berlingske Tidende 17.5. 1983 og 6.1. 1984), Kjeld Holm (Aarhuus Stiftstidende 25.3. 1983), Lars Holm (Dansk Kirketidende CXXXV 1983, s. 119-20), Poul Henning Jørgensen (Fyens Stiftstidende 30.4. 1983), Frede Ledet (Aktuelt 23.6. 1983), P. G. Lindhardt (Jyllands-Posten 25.3. og 14.11. 1983), Henri Nielsen (Vejle Amts Folkeblad 20.4. og 18.11. 1983), Lars Tjalve (Kristeligt Dagblad 24.8. 1983), Johannes Værge (Weekendavisen 22.4. og 9.12. 1983).

Salmer \& verdslige sange. Illustration[er af] Karl V. Larsen. Visoprint, København 1983. 77 s. [Forord af Karl V. Larsen s. 5-6.]

Sang-Vark. I-V (i 9 bind). 2. oplag. G. E. C. Gad, København 1982-84. [Følgende bind udkom i 1982-83: I,1-2: Sanguark til den danske kirke, 1982, s. 1-350 og 351-688; II: Sanguark til den danske kirke-skole, 1982, vi + 386 + XXXIX s.,; III,1-2: Salmer og kristelige digte 1809-1843, 1983, s. 1-280 og 281-548; IV,1-2: Salmer og kristelige digte 1844-1855, med efterslat fra 1836-1843, 1983, s. 1-280 og 281-548.] [Fotografisk optryk af 1. oplag (1944-64), med undtagelse af bd. VI (kommentarbindet, udsendt i 3 dele 1956-64).]

Anmeldt af: Jørgen Gleerup (Fyens Stiftstidende 9.12. 1982), Henrik Neiiendam (Weekendavisen 5.8. 1983), Doris Ottesen (Kristeligt Dagblad 10.9. 1983), Jørgen Pedersen (Fonix VII 1983, s. 76-78).

Skrifter $i$ udvalg. 2. udgave. Udgivet med efterskrift [s. 351-67] af Kaj Thaning. Gyldendal, København 1983. 367 s. [1. udgave, 1965 (Gyldendals Bibliotek/Dansk Litteratur, 6).]

Anmeldt af: Thyge V. Kragh (Vejle Amts Folkeblad 8.9. 1983), P. G. Lindhardt (JyllandsPosten 6.9. 1983), Doris Ottesen (Kristeligt Dagblad 24.10. 1983).

Statsmassig Oplysning - et udkast om samfund og skole. Udgivet af Selskabet for Dansk Skolehistorie ved K. E. Bugge og Vilhelm Nielsen. Nyt Nordisk Forlag, København 1983. 159 s. [K. E. Bugge, "Indledning ", s. 9-22; Vilhelm Nielsen, "Efterskrift", s. 79153; noter, s. 154-59.]

Anmeldt af: H. Engberg-Pedersen (Årbog for dansk Skolehistorie XVII 1983, s. 118-20), Jørgen Gleerup (Fyens Stiftstidende 31.5. 1983), Kjeld Holm (Aarhuus Stiftstidende 16.9. 1983), A[lbert] J[ohansen] (Folkeskolen C 1983, s. 1328-29), Olav Klonteig (Folkehøgskolen 1984, s. 41-42), Arne G. Larsen (Vestkysten 9.7. 1983), P.G. Lindhardt (JyllandsPosten 15.7. 1983).

To Dialoger om Hojskolen. 1. Academiet i Soer-en sod Drom. 2. Samtale mellem en Forfatter og en Bonde med Deltagelse af en Magister og en Naturforsker. Med tegninger af Susanne Errebo og med forord, efterskrift og noter af Dan Ch. Christensen. Forlaget Odin, Holbæk 1983. 128 s. [Efterskrift s. 58-120, noter s. 121-28.]

Velkommen igen, Guds engle små. Med originalgrafik af Henry Heerup. 2. udgave. Brøndums Forlag, København 1983. 27 upag. s. [1. udgave, 1972; nyt er et forord, s. 5-10, af Ejvind Larsen.]

Anmeldt af: Mogens Müller (Kristeligt Dagblad 29.11. 1983). 


\section{Separattrykte Afhandlinger etc.}

Allchin, A. M., N. F. S. Grundtvig. The Spirit as Life-giver. København 1983. 17 s. (Arken-Tryk, nr. 35.)

Bjerg, Svend, Den kristne grundfortelling. Studier over fortalling og teologi. Forlaget Aros, Århus 1981. 2. oplag, 1984. S. 298-346 (o: kapitlet "Grundfortællingen i N. F. S. Grundtvigs teologi“). (Teologiske Studier, 8.)

Disputats, forsvaret på Aarhus Universitet 10.12. 1981. "Deutsche Zusammenfassung “, s. 352-67 (af Grundtvig-kapitlet s. 364-67). - Se hertil: Arne Busk Madsen, "Grundtvig i Svend Bjergs teologiske korset", Tidehverv LVI 1982, s. 61-69; A. Pontoppidan Thyssen, "Historien, Grundtvig og Svend Bjerg. Opposition ved Bjergs disputats", Dansk teologisk Tidsskrift XLV 1982, s. 1-15. - Cf. også, om disputatsen generelt: Religionsvidenskabeligt Tidsskrift, nr. 1, 1982, s. 9-82 (Peter Kemp s. 9-26, Ole Davidsen s. 27-34, Jan Lindhardt s. 35-38, Per Bilde s. 39-61, og Svend Bjerg s. 6382).

[Blædel, Michael (red.),] Det levende Ord. C. A. Reitzels Forlag, København 1983. 133 s. (Modersmål-Selskabets årbog 1983.) [Indhold: Gustav Albeck, "Det levende Ord", s. 9-27; A. Pontoppidan Thyssen, "Grundtvigs opdagelse af Det levende Ord - i kirken ", s. 28-38; Morten Bredsdorff, "Grundtvigs brug af Det levende Ord - i samfundet", s. 39-47; Vilhelm Nielsen, "Grundtvigs brug af Det levende Ord - i skolen", s. 48-58; Frederik Christensen, "Samtalen i hjem, skole og undervisning ", s. 59-65; Jørgen Fafner, "Et skær af fortrolighed - Grundtvigs folkelige verskunst", s. 66-81; Niels Martin Jensen, "Nattergale eller uglesang - Grundtvig-sangen i går, i dag og i morgen ", s. 82-91; Jørgen I. Jensen, "Salmesang - gådesang ", s. 92-101; Svend Bjerg, "I begyndelsen var fortællingen", s. 102-11; Sophie Nedergaard, "Æventyret som fortælling", s. 112-22; Elsa Gress, "Det levende ords muligheder i massemedierne", s. 123-33.]

Anmeldt af: Aage Jørgensen (Handelsskolen XVII:4 1984, s. 83), Doris Ottesen (Kristeligt Dagblad 6.2. 1984).

Borum, Poul, Digteren Grundtvig. 1.-2. oplag. Gyldendal, København 1983. 281 s.

Anmeldt af: Hans Andersen (Jyllands-Posten 7.9. 1983), Harry Borup (Roskilde Tidende 20.9. 1983), Jens Brun (Højskolebladet 1983, s. 764-66), Søren Dissing (Vendsyssel Tidende 16.9. 1983), Peter Fischer-Møller (Fønix VIII 1984, s. 61-64), Jørgen Gleerup (Fyens Stiftstidende 9.9. 1983), Ketty Jensen (Kolding Folkeblad 1.10. 1983), Holger Jepsen (Dansk Kirketidende CXXXV 1983, s. 408-10), John Chr. Jørgensen (Politiken 10.9. 1983), Jens Kistrup (Berlingske Tidende 6.9. 1983), Thyge V. Kragh (Vejle Amts Folkeblad 27.9. 1983), Finn Stein Larsen (Weekendavisen 9.9. 1983), Johannes Møllehave (Ekstrabladet 6.9. 1983), Ebbe Kløvedal Reich (May Schack \& Carsten Jensen (red.), Litteratur/84 - en almanak, Tiderne Skifter, København 1983, s. 28-30), Hans Sølvhøj (Aktuelt 12.10. 1983), Ingolf Thomsen (Sjallands Tidende 9.9. 1983; Dagbladet 9.9. 1983; Nastved Tidende 17.9. 1983), Lars Tjalve (Kristeligt Dagblad 6.9. 1983).

Bredsdorff, Morten, Grundtvig og Sydsjalland. Historisk Samfund for Præstø Amt, Herlufmagle 1983. $43 \mathrm{~s}$. [Separattryk af årbogsbidrag, cf. u. IV ndf.]

Anmeldt af: Tage Taaning (Berlingske Tidende 24.9. 1983).

Dam, Poul, Politikeren Grundtvig. Forlaget Aros, Århus 1983. $96 \mathrm{~s}$. 
Anmeldt af: Søren Dissing (Vendsyssel Tidende 16.9. 1983), Vagn Dybdahl (Politiken 12.11. 1983), Bjarne Gregersen (Kolding Folkeblad 12.9. 1983), Lars Holm (Dansk Kirketidende CXXXV 1983, s. 410-11), Knud Larsen (Berlingske Tidende 8.9. 1983), P. G. Lindhardt (Jyllands-Posten 13.9. 1983), Erik Staffeldt (Politiken 6.9. 1983), Svend Erik Sørensen (Prasteforeningens Blad LXXIV 1984, s. 461), Leo Tandrup (Kristeligt Dagblad 8.9. 1983).

Dam, Poul, Nikolaj Frederik Severin Grundtvig (1783-1872). Translated by Reginald Spink. Royal Danish Ministry of Foreign Affairs, Copenhagen 1983. 72 s. [Også udgivet på fransk (77 s.), spansk (87 s.) og tysk (77 s.).]

Education for Life. International Conference on the Occasion of the Bicentenary of N. F. S. Grundtvig, Copenhagen, Denmark, September 10-14, 1983. Det danske Selskab/ The Danish Institute, Copenhagen 1983. 47 s. [Udgivet som bilag til Nordisk tidsskrift for voksenopplaring XVII:5-6 1983.] [Indhold bl.a.: Bertel Haarder, "Grundtvig - a Message to our Time", s. 2-4; A. M. Allchin, "Grundtvig. An English Appreciation", s. 5-11; K. Schultz Petersen, "The Prophecy of the Volva", s. 11-18; K. E. Bugge, "Grundtvig's Challenge to Modern Educational Thought", s. 18-21; Sv. Erik Bjerre, "The Folk High School - Grundtvig's Intuition on Adult Education", s. 21-25; Maria Luisa de Natale, "Grundtvig's Educational Ideas Viewed from South Italy", s. 25-29; Ramlal Parikh, "Educational Ideas of Grundtvig and Gandhi“, s. 29-31; Poul Dam, "Grundtvig's Vision of Mankind and his Ideas on 'folkelighed'", s. 31-36.]

Elbek, Jørgen, Grundtvig og Syvstjernen. Forlaget i Haarby, Hårby 1981. 66 s. [Fire artikler, de tre også offentliggjort i hhv. Grundtvig-Studier 1980, s. 7-22, Grundtvig-Studier 1981, s. 30-46, og Dansk Udsyn LXI 1981, s. 163-77.]

Anmeldt af: Anon. (Religionslareren, nr. 420, 1982, s. 30), Vilh. Gregersen (Prcesteforeningens Blad LXXIII 1983, s. 820-21), Mogens Müller (Kristeligt Dagblad 2.12. 1981)

Fang, Lotte, Roskilde-Riim. Fair-Print, Roskilde 1983. $47 \mathrm{~s}$. [Kommentarer til Grundtvigs lejlighedsdigt med fokus på Roskilde-stoffet; dele af digtet optrykkes.]

Fischer-Møller, Peter, Individ og fallesskab. En udviklingslinie i N. F. S. Grundtvigs forfatterskab (1806-1834). København 1983. 138 s. (Arken-Tryk, nr. 22.) [Offsetreproduceret specialeopgave.]

Futtrup, Jens, Digteren N. F. S. Grundtvig. Artikler 1930-1933 i "Grindsted Realskole"s arsskrift. Grindsted Bibliotek, Grindsted 1983. 54 s. (Lokalhistoriske skrifter, nr. 2.) [Indhold: "Op dog, Zion", s. 5-16; "Ordenes Vægt hos Grundtvig", s. 17-31; "Grundtvig-Kierkegaardsk Følgeskab», s. 32-40; "Dages det immer paany?», s. 41-48; Poul Borum, [Digteren Grundtvig (cf. ovf.), s. 158-64], s. 49-54.]

Grell, Helge, Skaberordet og billedordet. Studier over Grundtvigs teologi om ordet. Danske Boghandleres Kommissionsanstalt, København 1980. 205 s. (Skrifter udgivet af Grundtvig-Selskabet, XVII.)

Anmeldt af: Vilhelm Gregersen (Prasteforeningens Blad LXXI 1981, s. 752-54), T. Gudmand-Høyer (Højskolebladet 1981, s. 360-61), Viggo Mortensen (Information 22.1. 1981), Mogens Müller (Kristeligt Dagblad 10.1. 1981), Hellmut Toftdahl (GrundtvigStudier 1982, s. 74-86 [engelsk resumé s. 95-97]). - Cf. hertil: Jakob Fløe Nielsen, "Om skaberordet og billedordet - og kristologi “, Fonix V 1981, s. 75-81.

Greve, Ejnar, Ad Grundtvigs veje. Omkring 200-året for hans fodsel. Chr. Erichsen, København 1981. $95 \mathrm{~s}$. [Billedbog.]

Anmeldt af: Hans Andersen (Jyllands-Posten 18.11. 1981), Kirsten Boas (Politiken 29.11. 1981), Henning Jessen (Nastved Tidende 10.11. 1981), Th. V. Kragh (Vejle Amts Folke- 
blad 23.11. 1981), [Jens] Ravn [Olesen] (Kristeligt Dagblad 26.2. 1982), Rich. Teislev (Amtsavisen Randers 9.12. 1981), Mette Winge (Berlingske Tidende 30.12. 1981), vf. (Sjallands Tidende 2.12. 1981), mose (Fyens Stiftstidende 14.12. 1981).

Grundtvig-Studier 1979-1983. Udgivet af Grundtvig-Selskabet af 8. September 1947. Under redaktion af Gustav Albeck og William Michelsen. Danske Boghandleres Kommissionsanstalt, København 1979-83. 99, 98, 91, 99 og $104 \mathrm{~s}$.

1981) Anmeldt af: S[øren] D[issing] (Vendsyssel Tidende 28.4. 1982), Poul Engberg (Kristeligt Dagblad 17.2. 1982), Jens Ole Henriksen (Dansk Kirketidende CXXXV 1983, s. 46-48), P. G. Lindhardt (Jyllands-Posten 23.2. 1982).

1982) Anmeldt af: Poul Engberg (Kristeligt Dagblad 7.2. 1983), P. G. Lindhardt (Jyllands-Posten 14.3. 1983).

Grundtvig's Ideas in North America. Influences and Parallels. [Papers presented at a Grundtvig workshop arranged by Scandinavian Seminar College, Holte, Denmark, June 1983.] Det danske Selskab/The Danish Institute, Copenhagen 1983. 173 s. [Indhold bl.a.: Sally C. Opstein, "Two Educators: Grundtvig and Dewey", s. 13-16; Myles Horton, "Influences on Highlander Research and Education Center, New Market, Tennessee, USA ", s. 17-31; Gunnar Bergendal, "Knowledge in a Free Society “, s. 3240; James S. Hamre, "N. F. S. Grundtvig and Georg Sverdrup. Some Notes on their Educational Theories", s. 41-52; Solidelle Wasser, "Grundtvig's Impact on Thorstein Veblen", s. 53-60; Christian Thodberg, "Grundtvig the Hymnwriter", s. 61-87; Niels Lyhne Jensen, "Grundtvig and Mythology", s. 88-101; Helge Severinsen, "Grundtvig's Theological and Educational Ideas - a Personal View «, s. 102-08; Dorothy Burton. Skårdal, "Grundtvigianism in Danish-American Literature", s. 109-21; Enok Mortensen, "Grundtvig's Influence on American Education", s. 122-32; Royce S. Pitkin, "An Informal Comparison of the Educational Concepts of Grundtvig and Dewey“, s. 133-37; Sven Burmester, "Reflections on the Political Dimensions of Grundtvigianism", s. 151-56; K. Patricia Cross, "Threads of Grundtvig in the Fabric of Adult Education in the United States ", s. 157-61.]

Helweg, Hjalmar, N. F. S. Grundtvigs Sindssygdom. 2. oplag. Janssenpharma, [Birkerød 1983]. 128 s. [1. oplag, Henrik Koppels Forlag, København 1918; udgivet af Dansk Medicinsk-Historisk Selskab.]

Henningsen, Bernd, Politik eller kaos. Berlingske Forlag, København 1980. S. 234-57 (o: kapitlet "N. F. S. Grundtvig: Profet for en civilteologi«). [Oprindelig offentliggjort på tysk 1977; cf. Grundtvig-Studier 1979, s. 78.]

Anmeldt af: Radko Kejzlar (Edda LXXXII 1982, s. 57-59).

Henningsen, Hans, Folkelige temaer hos Grundtvig og Logstrup. Forlaget Aros, Århus 1983. $101 \mathrm{~s}$.

Anmeldt af: Jørgen Gleerup (Fyens Stiftstidende 29.10. 1983), Helge Grell (Højskolebladet 1983, s. 733-34), P. G. Lindhardt (Jyllands-Posten 20.10. 1983), Doris Ottesen (Kristeligt Dagblad 14.11. 1983), Svend Erik Sørensen (Information 23.12. 1983). - Cf. interview af Claus Grymer (Kristeligt Dagblad 15.10. 1983).

Holt, Thyra, Minderige Steder i Grundtvigs Liv. En fotografisk Billedbog med Tekster af Grundtvig og Ernst J. Borup. Forord: Roar Skovmand. 2. oplag. Rhodos, København 1983. 178 s. [1. oplag, 1955.]

Høirup, Henning, Fra døden til livet. Grundtvigs tanker om liv og død. 2. oplag. G. E. C. Gad, København 1983. 112 s. [1. oplag, Gyldendal, København 1954.]

Anmeldt af: Jørgen Gleerup (Fyens Stiftstidende 7.10. 1983), Kjeld Holm (Aarhuus 
Stiftstidende 6.12. 1983), Morten Kvist (Prasteforeningens Blad LXXIV 1984, s. 171-73). Iversen, Hans, Kvalitet og tolkning i hverdagslivet - noget om Grundtvig ud fra temaet socialisation og teologi. [København 1981.] $28 \mathrm{~s}$. (Arken-Tryk, nr. 2.) [Foredrag holdt 11.3. 1981.]

Iversen, Hans, Tro, håb og karlighed. Sakularisering og socialisation grundtvigsk forstået. FKTryk, Århus $1982.87 \mathrm{~s}$.

Iversen, Hans, København og sakulariseringen $i$ Grundtvigs perspektiv. København 1983. 21 s. (Arken-Tryk, nr. 28.) [Foredrag holdt ved Grundtvigsk Konvent 17.11. 1982.]

Jensen, Jørgen I. \& Erik A. Nielsen (red.), Efterklange - et Grundtvig-seminar. Centrum, Århus 1983. 187 s. [Indhold: Ove Nathan, "Tale ved åbningen af Grundtvig-seminaret 16. maj 1983", s. 7-8; A. Pontoppidan Thyssen, "Kristendom og menneskesyn hos den ældre Grundtvig", s. 9-19; Torben Damsholt, "Myter og mytologi", s. 20-33; Sven-Aage Jørgensen, "Grundtvig og Tyskland - dialogen der blev væk", s. 34-42; Peter Fischer-Møller, "Individ og fællesskab“, s. 43-51; Kai Hørby, "Grundtvig og universitetet", s. 52-63; Margaretha Balle-Petersen, "Grundtvigske kulturmiljøer", s. 64-79; Aage Henriksen, "Fra digter til reformator", s. 80-92; Flemming LundgreenNielsen, "Mellem romantik og oplysningstid - Grundtvig i litteraturhistorisk perspektiv", s. 93-103; K. E. Bugge, "Dialektisk prdagogik og levende vekselvirkning", s. 104-15; Christian Thodberg, "Grundtvig som prædikant", s. 116-36; Leif Grane, "Grundtvigs kirkelige anskuelse", s. 137-44; Vilhelm Nielsen, "Den tredje verden og Grundtvig", s. 145-53; Johs. H. Christensen, "Poesi og teologi hos Grundtvig", s. 154-75; Ejvind Larsen, "Øjeblikkets politik - Grundtvigs øjeblik «, s. 176-84; "Redaktionens efterskrift", s. 165-87.]

Anmeldt af: P. G. Lindhardt (Jyllands-Posten 6.10. 1983), Erik H. Madsen (Vestkysten 3.11. 1983), Bent Windfeld (Kristeligt Dagblad 7.12. 1983).

Kemp, Peter (red.), Sprog. Tale og skrift. Indlæg fra Filosofisk Grundtvig-kongres afholdt på Københavns Universitet 9.-10. september 1983. Forlaget Aros, Århus 1984. $115 \mathrm{~s}$. [Indhold: Peter Kemp, "Grundtvigs kritik af skriften", s. 9-18; Justus Hartnack, "Sprogets filosofiske betydning", s. 19-38; Jon Hellesnes, "Om ironi“, s. 39-49; Paul Ricoeur, "Tale og Skrift", s. 51-66; Michael Dummett, "Kan sproget benyttes ukorrekt?«, s. 67-96; Hans-Georg Gadamer, "Undervejs til skriften?", s. 97-111.]

Anmeldt af: Bjarne Christensen (Prasteforeningens Blad LXXIV 1984, s. 297-99).

Klonteig, Olav, Grundtvigs opplysningstankar - og vår tids skole- og samfunnsdebatt. PUFF/ Arbetsgruppen för pedagogiskt utvecklingsarbete för folkhögskolan, Stockholm 1983. iv, 44 s. (Rapport nr. 96 från PUFF, del 2.) [Cf. ndf. u. Paul Terning.]

Kristeligt Dagblad. Særtryk af 10 kronikker bragt omkring N. F. S. Grundtvigs 200 års dag. 1983. 24 s. [Cf. ndf. u. V: Olav Akerlie, K. F. Brondbjerg, Poul Dam, Kresten Drejergaard, Poul Engberg, Kristian Thule Hansen, Andreas Haarder, Olav Klonteig, P. G. Lindhardt og Erik A. Nielsen.]

Larsen, Ejvind, Det levende ord. Om Grundtvig. 1.-2. oplag. Rosinante, Charlottenlund 1983. 336 s. [Heri: Gert Posselt, "Tidstavle over Grundtvigs liv og samtid ", s. 301-36.] Anmeldt af: Tage Albertsen (Fyens Stiftstidende 9.6. 1983), Bo Bjørnvig (Weekendavisen 3.6. 1983), Johs. H. Christensen (Kristeligt Dagblad 3.6. 1983), Poul Engberg (Flensborg Avis 10.6. 1983), Peter Fischer-Møller (Arken V:4 1983, s. 61-66), Knud Hansen (Fyens Stiftstidende 17.6. 1983; Aarhuus Stiftstidende 27.6. 1983), Lars Holm (Dansk Kirketidende CXXXI 1983, s. 233-35), Bertel Haarder (Viborg Stifts Folkeblad 22.6. 1983), Ketty Jensen (Herning Folkeblad 13.6. 1983), Kurt Johansson (Presteforeningens Blad LXXIII 
1983, s. 471-73), John Chr. Jørgensen (Politiken 10.9. 1983), Peter Kemp (Politiken 1.6. 1983), Olav Klonteig (Folkehøgskolen 1983, s. 150-51), P. G. Lindhardt (Jyllands-Posten 3.6. 1983), Gunhild Nissen (Højskolebladet 1983, s. 545), Søren Schou (Politisk Revy, nr. 446, 7.10. 1983, s. 20 og 22), Villy Sørensen (Information 15.6. 1983; optrykt i: May Schack \& Carsten Jensen (red.), Litteratur/84 - en almanak, Tiderne Skifter, København 1983, s. 26-28), Chr. Westergård (Unge Padagoger 1983, nr. 5, s. 33-35). - Cf. interviews af Annagrethe Skov (Frederiksborg Amts Avis 4.9. 1983), Jan Stage (Politiken 1.6. 1983) og Annelise Vestergaard (Jyllands-Posten 5.6. 1983). - Cf. også: Jørgen Gleerup, "De danske Larsener", Højskolebladet 1984, s. 200-02; Johannes Lauridsen, "Bemærkninger til Ejv. Larsens Grundtvigbog “, Dansk Kirketidende CXXXV 1983, s. 356-59; Lars Paludan, "Tredie gang bliver lykkens gang! «, Dansk Udsyn LXIII 1983, s. 322-32; Kaj Thaning, "Ejvind Larsens Grundtvig", Dansk Udsyn LXIV 1984, s. 23-41.

Larsen, Ejvind, Grundtvig - og noget om Marx. 2. udgave. København 1982. 86 s. (ArkenTryk, nr. 13.) [Fotografisk optryk af 1. udgave, 1974.]

Larsen, Finn Stein \& Erik Bernstorff (red.), Et Grundtvig-Festskrift. I anledning af hans 200årsdag. Grundtvig-festskriftredaktionen/ ̊̊rhus Katedralskole, Århus 1983. 77 s. [Artikler af Gustav Albeck, Poul Nyboe Andersen, Aage Bertelsen, Harald EngbergPedersen, J. S. Hjort Eriksen, Karin Flensborg, Ulla Hammerich, Svend Heuer, Erik Hoffmeyer, Arthur Ilfeldt, Jan Lindhardt, Marie-Louise Paludan, Clemens Pedersen, Arne Fog Petersen, Helge Qvortrup og Troels Rønsholdt; digt af Kristen Bjørnkjær; tegninger af Lene Adler Petersen; afslag fra Christian Braad Thomsen.]

Lundgreen-Nielsen, Flemming, Det handlende ord. N. F. S. Grundtvigs digtning, litteraturkritik og poetik 1798-1819. I-II. G. E. C. Gad, København 1980. 991 s. English Summary, s. 930-42. (Skrifter udgivet af Grundtvig-Selskabet, XVI.)

Disputats, forsvaret på Københavns Universitet 16.12. 1980. - Anmeldt af: Gustav Albeck (Jyllands-Posten 16.12. 1980), F. J. Billeskov Jansen (Berlingske Tidende 15.1. 1981), Torben Brostrøm (Information 17.12. 1980), Johs. H. Christensen (Kristeligt Dagblad 16.12. 1980), Jørgen Elbek (Politiken 16.12. 1980), P. G. Lindhardt (Berlingske Tidende 14.12. 1980), Paul Heide Ottosen (Weekendavisen 12.12. 1980), - $r$ (Aalborg Stiftstidende 28.7. 1981) - Cf. hertil: Christian Thodberg, "Om Grundtvigs poetik med særligt henblik på den bibelske inspiration ", Grundtvig-Studier 1982, s. $20-45$ (engelsk resumé s. 90-93). - Cf. også: Flemming Lundgreen-Nielsen, "Det handlende ord", Magisterbladet 1981, nr. 3, s. 15-16.

Mogensen, Kaj, En fortalling om Grundtvig. 16 s. [Tillæg til Religionslareren, 79. årg., nr. 1, 1983.]

Anmeldt af: Mogens Müller (Kristeligt Dagblad 2.2. 1983).

N. F. S. Grundtvig. Theolog og kirkelarer. Predikener og foredrag fra 200-året. Udvalget for Konvent for Kirke og Theologi, Sabro 1983. 100 s. [Indhold: I: "To prædikener" (Regin Prenter, "Prædiken over Romerbrevet 11,33-36 [...]", s. 9-12; Jørgen Glenthøj, "Prædiken over Matthæusevangeliet 6,24-34 [...]", s. 13-19); II: „Fem foredrag holdt på Konvent for Kirke og Theologi 30.-31. oktober 1983 i Århus" (Hejne Simonsen, "Grundtvig som ekseget", s. 20-32; Søren Poulsen, "Ordet er dig nær. Bibeltime over Romerbrevet, kap. 9, v. 30-kap. 10, v. 13 ", s. 33-41; Arthur McDonald Allchin, "Grundtvig's Catholicity", s. 42-53; Regin Prenter, "Grundtvigs treenighedslære", s. 54-76; Jørgen Glenthøj, "Injurieprocessen mod Grundtvig 1825-26“, s. 77-99).]

Natale, Maria Luisa de, L'educazione per la vita. N. F. S. Grundtvig Pedagogista e Educatore Danese. Istituto Danese di Cultura/Bulzoni Editore, Roma 1980. $242 \mathrm{s.}$ 
Nissen, Henrik S. (red.), Efter Grundtvig. Hans betydning i dag. Gyldendal, København 1983. 204 s. [Indhold: Henrik S. Nissen, "Samfundsudviklingen og det grundtvigske", s. 9-22; Ole Wivel, "Med Grundtvig i ryggen", s. 23-32; Karl Otto Meyer, "Det nationale - blev det noget særligt i Danmark? ", s. 33-45; Herbert Pundik, "Folk, hvad er vel folk i grunden?", s. 46-47; Frode Jakobsen, "National frihed - international solidaritet", s. 48-62; Torben Damsholt, "'Rom', 'det tyske' og 'Guds udvalgte folk' oversat til brug for danskere i 1980 'erne", s. 63-80; K. B. Andersen, "Grundtvig, grundtvigianisme og lønarbejdere", s. 81-91; Claus Bjørn, "Landbrug og landbosamfund anno 1983 - og så 'det grundtvigske' ", s. 92-110; Bertel Haarder, "Det grundtvigske i skolen og uddannelsen“, s. 111-19; Aage Rosendal Nielsen, "Det selvbestaltede", s. 120-35; Margaretha Balle-Petersen, "Grundtvig og momsen. Om det folkelige og folket i forsamlingshusene", s. 136-54; Thomas Bredsdorff, "Mytologier", s. 15567; Benny Andersen, "Fællessang. Hvorfor synger vi?», s. 168-75; Ebbe Kløvedal Reich, "Nornens røst, satellittransmitteret - uafsluttet historisk-poetisk dialog", s. 176-90; Niels Thomsen, "Den kristne børnelærdom, så vi kan fortælle den til vore børn ", s. 191-204.]

Anmeldt af: Harry Borup (Roskilde Tidende 9.9. 1983), Søren Dissing (Vendsyssel Tidende 16:9. 1983), Ulf Gudmundsen (Vestkysten 9.9. 1983), J. B. Holmgård (Politiken 7.9. 1983), Thyge V. Kragh (Vejle Amts Folkeblad 24.9. 1983), Ejvind Larsen (Information 8.9. 1983), P. G. Lindhardt (Jyllands-Posten 6.9. 1983), Tune Nyborg (Kolding Folkeblad 28.9. 1983), Jens Ravn Olesen (Kristeligt Dagblad 22.9. 1983), Svend Erik Sørensen (Fyens Stiftstidende 8.9. 1983), Ingolf Thomsen (Flensborg Avis 6.9. 1983).

Nørfelt, Henrik Fibiger, En ny Sang i Danas Mund. En registrering og vurdering af melodivalget for og nu til N. F. S. Grundtvigs a-salmer i Den danske Salmebog. P. Haase \& Søn, København 1983. 256 s. [Indledning s. 9-30; registreringen omfatter 170 salmer.]

Anmeldt af: Ea og Erik Dal (Hymnologiske Meddelelser XIII 1984, s. 50-62), Lasse Everlöf (Prasteforeningens Blad LXXIV 1984, s. 479-80), P. G. Lindhardt (JyllandsPosten 20.12. 1983).

Prenter, Regin, Den kirkelige anskuelse. En indforelse i N. F. S. Grundtvigs folkelige og kristelige grundtanker. Udgivet af Udvalget for Konvent for Kirke og Theologi. Forlaget Savanne, Christiansfeld 1983. 115 s. ["... en let bearbejdet udgave af 8 forelæsninger ... holdt på Menighedsfakultetet i Århus ".]

Anmeldt af: Helge Noe-Nygaard (Prosteforeningens Blad LXXIV 1984, s. 142-43).

Rasmussen, Mogens, En konstrueret dagbog for Grundtvigs 3 Englandsrejser 1829-31. København 1983. 36 s. (Arken-Tryk, nr. 31.)

Reich, Ebbe Kløvedal, Frederik. En folkebog om Grundtvigs tid og liv. 3. udgave. Gyldendal, København 1981. 367 s. [Tranebog; 2. oplag, 1983.]

Oplagstal: Den "ordinære" udgave er siden 1972 udsendt i 10 oplag, ialt 29900 eks.; bogklubudgaven er siden 1973 udsendt i 3 oplag (oplagstallet uoplyst "af principielle grunde"); tranebogsudgaven er siden 1981 udsendt i 2 oplag, ialt 19000 eks.

Hertil: Helene Kongsbach \& Anne Majken Snerup Rud, Ebbe Klovedal Reich: Frederik. Gyldendal, København 1983. 63 s. (Trane-studiehæfte.)

Siljander, Pauli, N. F. S. Grundtvigin sivistysnäkemys ja kansanopiston tehtävä. Oulu 1982. iv, 141 s. (Oulun yliopiston kasvatustieteiden tiedekunnan tutkimuksia, 11/1982.) [Om Grundtvigs kulturbegreb og folkehøjskolens opgave.]

Siljander, Pauli, N. F. S. Grundtvigin sivistysidea ja kansanopiston kasvatustavoitteet. Oulu 1982. vi, 48 s. (Oulun yliopiston kasvatustieteiden tiedekunnan tutkimuksia, 12/1982.) 
[Akademisk avhandling, der sammenfatter tre tidligere forskningsrapporter, bl.a. den ovf. nævnte.]

Slumstrup, Finn (red.), Grundtvigs oplysningstanker og vor tid. Nordisk Folkehøjskoleråd, København 1983. 127 s. [Indhold: Finn Slumstrup, "En skitse af Grundtvigs liv ", s. 834; ds., "Kernebegreber i Grundtvigs oplysningstanker ", s. 36-59; N. F. S. Grundtvig, "Om indretningen af Sorø Akademi til en folkelig højskole", s. 60-67; Olav Akerlie, "Grundtvig i Noreg", s. 68-82; Paul Terning, "Grundtvig i Sverige", s. 84-97; Gustav Björkstrand, "Grundtvig i Finland ", s. 98-115; litteraturhenvisninger s. 116-27.] [Også udgivet på finsk.]

Terning, Paul, N. F. S. Grundtvig. Ett liv och ett levande arv. PUFF/Arbetsgruppen för pedagogiskt utvecklingsarbete för folkhögskolan, Stockholm 1983. vi, 77 s. (Rapport nr. 96 från PUFF, del 1.) [Cf. ovf. u. Olav Klonteig.]

Thaning, Kaj, Grundtvig. Dansk Friskoleforening, [Fåborg] 1983. $126 \mathrm{~s}$.

Anmeldt af: A[lbert] J[ohansen] (Folkeskolen C 1983, s. 1333).

Thaning, Kaj, Grundtvig. Med en efterskrift af Erling Nielsen. Gyldendal Norsk Forlag, Oslo 1983. 144 s. [Efterskrift, "Grundtvig og Norge", s. 127-43; herudover er bogen identisk med den ovf. nævnte.]

Anmeldt af: Svend Gjesdahl (Arbeiderbladet 26.1. 1984), Ø.H. (Kristen Folkehogskole, dec. 1983, s. 18-19), Karstein M. Hansen (Kirke og Kultur LXXXIX 1984, s. 62-64), Arild Mikkelsen (Folkehøgskolen LXXX 1984, s. 40-41), Jan Inge Sørbø (Dagen [Bergen] 31.10. 1983).

Thodberg, Christian \& Anders Pontoppidan Thyssen (red.), N. F. S. Grundtvig. Tradition and Renewal. Grundtvig's Vision of Man and People, Education and the Church, in Relation to World Issues Today. Translated from the Danish by Edward Broadbridge. Det danske Selskab/The Danish Institute, Copenhagen 1983. 428 s., 24 pl. [Indhold: Anders Pontoppidan Thyssen \& Christian Thodberg, "A Brief Biography", s. 9-16. (I: "The Younger Grundtvig(:) Flemming Lundgreen-Nielsen, "Grundtvig and Romanticism ", s. 19-43; William Michelsen, "Grundtvig's Christian Breakthrough 1810-12 The Strange Metamorphosis in Grundtvig's Life", s. 44-51; Sigurd Aage Aarnes, "Grundtvig the Historian", s. 52-71; Andreas Haarder, "Grundtvig and the Old Norse Cultural Heritage", s. 72-86; Anders Pontoppidan Thyssen, "Grundtvig's Ideas on the Church and the People up to 1824", s. 87-120. (II: "Grundtvig's Basic Ideas on the Church and Education":) Christian Thodberg, "Grundtvig the Preacher - the Poet in the Pulpit ", s. 123-59 (incl. "Sermon for the 16th Sunday after Trinity 1823 (Luke 7:1117)«, s. 141-52); Christian Thodberg, "Grundtvig the Hymnwriter ", s. 160-96; Niels Thomsen, "Grundtvig in the Mirror of the Early Church", s. 197-210; K. E. Bugge, "Grundtvig's Educational Ideas", s. 211-25; Anders Pontoppidan Thyssen, "Grundtvig's Ideas on the Church and the People 1825-47«, s. 226-92. (III: "The Later Years and Grundtvigianism ":) William Michelsen, "Grundtvig's Place in Danish Intellectual Thought - with Particular Regard to Søren Kierkegaard ", s. 295-302; Birgitte Thyssen, "Grundtvig and Grundtvigianism as a Political Factor", s. 303-20; Roar Skovmand, "Grundtvig and the Folk High School Movement ", s. 321-43; Anders Pontoppidan Thyssen, "Grundtvig's Ideas on the Church and the People 1848-72«, s. 344-70; Anders Pontoppidan Thyssen, "Grundtvigianism as a Movement until around 1900", s. 371-94; Jørgen I. Jensen, "A Brief Survey of Grundtvig Literature", s. 395-411; "A Grundtvig Bibliography", s. 412-23.]

Thodberg, Christian \& Anders Pontoppidan Thyssen (red.), N. F. S. Grundtvig. Tradition 
und Erneuerung. Grundtvigs Visionen von Mensch, Volk, Erziehung und Kirche, und ihre Bedeutung für die Gegenwart. Übersetzung ins Deutsche: Eberhard Harbsmeier. Det danske Selskab/Dänisches Institut, Kopenhagen 1983. 479 s., 24 pl. [Tysk udgave af ovennævnte; "Literatur-Verzeichnis", s. 443-73, hvis afsnit D, "Bibliographie über Grundtvig-Literatur in nichtskandinavischen Sprachen", s. 452-73, er basis for de kortere bibliografier i den engelske og den franske udgave.]

Thodberg, Christian \& Anders Pontoppidan Thyssen (red.), N. F. S. Grundtvig. Tradition et Renouveau. La conception de l'homme et du peuple, de l'éducation et de l'Eglise chez Grundtvig, à la lumiěre des prěoccupations du monde d'aujourd'hui. Traduits du danois par Jacques Piloz et Patrick Lavaud. Det danske Selskab/Institut Danois d'Information et d'Echanges culturels, Copenhague 1983. 444 s., 24 pl. [Fransk udgave af ovennævnte; "Appendice bibliographique", s. 433-39.]

Thodberg, Christian \& Anders Pontoppidan Thyssen (red.), Grundtvig og grundtvigianismen i nyt lys. Hovedtanker og udviklingslinier. Fra de senere års Grundtvigforskning. Forlaget ANIS i samarbejde med Det danske Selskab, Århus 1983. 381 s., 24 pl. [Dansk udgave af ovennævnte; Jørgen I. Jensens orientering om Grundtvig-litteraturen samt de bibliografiske oplysninger er udeladt.]

Anmeldt af: Hans Raun Iversen (Presteforeningens Blad LXXIV 1984, s. 624-28), Doris Ottesen (Kristeligt Dagblad 15.3. 1984), Kaj Thaning (Højskolebladet 1984, s. 315-17).

Vogel, Norbert \& Hermann Scheile (red.), Lernort Heimvolkshochschule. Eine deutschdänische Untersuchung zur Positionsbestimmung der Heimvolkshochschule mit ergänzenden Beiträgen aus den Niederlanden, Österreich und der Schweiz. Übersetzungen von Else Kjær und Norbert Vogel. Ferdinand Schöningh, Paderborn/München/Wien/Zürich 1983. 347 s. (Weiterbildung. Schriftenreihe für Theorie, Praxis und Forschung, 11.) [Indhold bl.a.: Hans Henningsen, "Der Beitrag N.F.S. Grundtvigs zur theoretischen Grundlegung der dänischen (Heim-)Volkshochschule", s. 21-39; Ole Breinholdt, "Die Grundtvigsche Ideologie und die (Heim-)Volkshochschule. Über die gesellschaftliche Funktion der dänischen Volkshochschule", s. 40-55; Bernd Henningsen, "Grundtvig und die deutsche Philosophie. Eine Übersicht", s. 56-68; Martha Friedenthal, "Die Bedeutung Grundtvigs für die Heimvolkshochschule in Deutschland - eine rezeptionsgeschichtlicher Beitrag zur Erwachsenenbildung in der Weimarer Republik«, s. 69-125.]

Warming, Per (red.), Fremtidens videnskab. En debatbog om Grundtvigs videnskabssyn og vor tid. 1983. 287 s. [Indhold: N. F. S. Grundtvig, "Om Nordens videnskabelige Forening ", s. 9-47; Poul Engberg, "Göteborgskriftets historie", s. 48-69; Henning Eichberg, "Ommytologisering. N. F. S. Grundtvigs, Michail Bakunins og indianernes kritik af videnskaben og magten", s. 70-92; H. C. Hansen, "Poul la Cour - en grundtvigsk naturvidenskabsmand ", s. 93-114; Jesper Hoffmeyer, "Dialektoriet for sans og samling", s. 115-25; Jørgen I. Jensen, "Universitetet synger. Videnskaben og det musiske", s. 126-41; Olav Klonteig, "Frå Grundtvigs Göteborgtanke til Nordens folkliga Akademi", s. 142-62; Ejvind Larsen, "Forskningen for folket", s. 163-74; Ejvind Larsen, "Øjeblikket", s. 175-84; Ejvind Larsen, "Prædiken", s. 185-91; Anne Lindhardt, "Psykiatri og videnskab", s. 192-207; Niels I. Meyer, "Eksperter, græsrødder og Grundtvig ", s. 208-17; Erik A. Nielsen, "Levende råd", s. 218-34; Peter Nilson, "En lyslevende vidskab'. Reflektioner kring Grundtvig och vetenskapen", s. 235-46; Per Nørgård, "Immer Lysten driver Værket ...' ", s. 247-55; Ebbe Kløvedal Reich, "Den frugtbare modsigelse", s. 256-65; Karen Marie Mortensen \& Per War- 
ming, "Nordisk videnskab. Grundtvigs videnskabssyn i vor tid", s. 266-87.]

Anmeldt af: Jørgen Gleerup (Fyens Stiftstidende 5.12. 1983), Jean (Vejle Amts Folkeblad

27.12. 1983), Søren Kjørup (Information 10.1. 1984), P. G. Lindhardt (Jyllands-Posten

3.1. 1984), Erik H. Madsen (Vestkysten 22.2. 1984), Vilhelm Nielsen (Kristeligt Dagblad 30.12. 1983), Rich. Teislev (Amtsavisen Randers 31.12. 1983).

\section{Afsnit i litteraturhistoriske o. a. Fremstillinger}

Albeck, Gustav, Universitet og folk. Bidrag til den folkelige universitetsundervisnings historie $i$ Danmark med et udblik til Folkeuniversiteterne $i$ Norge og Sverige. Gyldendal, København 1984. 423 s. Se reg.

Behrend, Harald \& Norbert Lochner, Geschichte und Gegenwart der Heimvolkshochschulen in Dänemark. Verlag A. Fromm, Osnabrück 1966. S. 68-80 (o: afsnittet "Ursprung und Gestaltung durch Grundtvig “). (Beiträge zur Erwachsenenbildung, 11.)

Anmeldt af: Roar Skovmand (Grundtvig-Studier 1983, s. 87-89).

Björkstrand, Gustav, "Skolan för livet. Huvuddragen i Grundtvigs pedagogiska tänkande“. I hans: Kristen fostran i kyrka och skola. Vasa 1978 S. 35-57. (Rapporter från Pedagogiska Fakulteten, Åbo Akademi, 6/1978.)

Bodenstein, Eckhard, Skolefrihed in Dänemark. Studien zur Entstehung eines schulpolitischen Prinzips. (Privattryk,) Tønder 1982. 401 s. [Om Grundtvig spec. s. 26-28, 80-82, 8688, 93-97, 232-35, 349-51; cf. reg.]

Anmeldt af: Hanne Engberg (Årbog for dansk skolehistorie XVII 1983, s. 114-16), Elin Fredsted (Skandinavistik XIII 1983, s. 73-74).

Bojesen, Lars Bo \& Jan Lindhardt, Samvittigheden. Berlingske Forlag, København 1979. S. 191-93.

Borgen, Sven, Dialogen i voksenundervisningen. Forum, København 1981. S. 33-49 (0: kapitlet "Grundtvig").

Borum, Poul, Danish Literature. A Short Critical Survey. Det danske Selskab, Copenhagen 1979. S. 34-37.

Brøndsted, Mogens, "1800-1830: Dänemark “. I: Nordische Literaturgeschichte. I: Von den Anfangen bis zum Jahre 1860. Redigiert von Mogens Brøndsted. Übersetzt von HansKurt Mueller. Wilhelm Fink Verlag, München 1982. S. 297-306. [Dansk/norsk/svensk udgave 1972.]

Bugge, K. E., Padagogiske grundideer. 3. forøgede udgave. Berlingske Forlag, København 1981. 225 s. [Om Grundtvig s. 34-37 og 200-01.] [1. udgave, 1969/1973; 2. forøgede udgave 1974/1977.]

Bukdahl, Jørgen K., Frihed og frigørelse. Filosofi, teologi, kulturdebat 1956-1979. Artikler og essays i udvalg ved Jan Lindhardt. Med en bibliografi udarbejdet af Niels Clemmensen. Forlaget Aros, Århus 1980. 336 s. [Heri s. 61-66, 67-71 og 307-12 anmeldelser af Kaj Thanings Menneske forst -, P. G. Lindhardts Grundtvig og Jørgen Elbeks Fra Grundtvig til Goethe.]

Bukdahl, Jørgen K., I den teologiske kreds. Artikler og afhandlinger samlet og redigeret af Hans Hauge, Kjeld Holm, Poul Henning B. Jørgensen og Jan Lindhardt. Arkona, Århus 1981. 192 s. [= Kredsen, 48. årg., nr. 1-2, 1981.] [Heri s. 29-34, 35-39 og 40-43 
anmeldelser af Grundtvig-Studier 1964 og 1965, samt K. E. Løgstrup \& Götz Harbsmeier (red.), Kontroverse um Kierkegaard und Grundtvig, I.]

Bukdahl, Jørgen K., Om Søren Kierkegaard. Artikler i udvalg ved Jan Lindhardt. C. A. Reitzels Boghandel, København 1981. 215 s. [Heri s. 9-15 og 95-99 anmeldelser af Søren Holms Grundtvig und Kierkegaard og P. G. Lindhardts Konfrontation.]

Degerman, Allan, m. fl. (red.), Svensk folkhögskola 100 år. I-IV. Bokförlaget Liber, Uddevalla 1968. [Spec. henvises til I, s. 41-44, 50-51 og 63-72, samt II, s. 15-28; cf. reg.]

Egebak, Niels, "Om at tilskrive sig Troens rare Klenodie". I hans: Skrift, subjekt, fiktion. Arena, Viborg 1980. S. 13-24. [Om "Hil dig, Frelser og Forsoner!«] [Oprindelig offentliggjort i Grundtvig-Studier 1971, s. 90-97.]

Fafner, Jørgen, Tanke og tale. Den retoriske tradition $i$ Vesteuropa. C. A. Reitzel, København 1982. S. 411-16. Cf. reg.

Halvorsen, Erik, Danske digtere. Kortfattet dansk litteraturhistorie. Aschehoug, København 1982. S. 34-37.

Hansen, Ib Fischer, Jens Anker Jørgensen, Knud Michelsen, Jørgen Sørensen og Lars Tonnesen (red.), Litteraturhåndbogen. Gyldendal, København 1981. S. 372-76. [Forfatterbiografi skrevet af Knud Michelsen.]

Helweg, Hjalmar, "Om Grundtvig". I hans: Om ingenting og andre skrifter. I udvalg ved Palle Eisenhardt. Christtreus Bogtrykkeri, København 1969. S. 75-87. [Et uddrag af bogen N. F. S. Grundtvigs Sindssygdom, 1918; cf. ovf. u. II.]

Hultberg, Helge, Den aldre Henrich Steffens, 1811-1845. C. A. Reitzels Boghandel, København 1981. S. 73-79. Cf. reg.

Hørby, Kai, Den nationale historieskriuning i Danmark. Den danske historiske Forening, København 1978. S. 20-26 (0: afsnittet "Grundtvig og nationalhistorien"). (Skrifter udg. af Det historiske Institut ved Københavns Universitet, 8.)

Ilsøe, Harald \& Kai Hørby, "Historie“. I: Povl Johs. Jensen (red.), Kobenhavns Universitet 1479-1979. X: Det filosofiske Fakultet, 3. del. G. E. C. Gad, København 1980. Spec. s. 404-06 og 407-09. Cf. reg. s. 572.

Jespersen, Per, "N. F. S. Grundtvig". I hans: Dansk litteraturhistorie for 4. og 5. klasse. SKForlag, Randerup 1983. S. 30-37.

Kemp, Peter, "Den hemmelige gru for maskineriet (Grundtvigs observation) «. I: PierrePhilippe Druet, Peter Kemp \& Georges Thill, Henimod et teknologisk demokrati. Bearbejdet af Peter Kemp. Lindhardt \& Ringhof, København 1980. S. 54-55.

Korsgaard, Ove, Kampen om kroppen. Dansk idrats historie gennem 200 år. Gyldendal, København 1982. S. 48-49, 98-100 og 160-61. Cf. reg.

Mabire, Jean, "Nicolas Grundtvig (1783-1872)". I hans: Les grands aventuriers de l'histoire. Les éveilleurs de peuples. Fayard, Paris 1982. S. 357-419 og 435-37.

Mortensen, Viggo, Teologi og kritik. Aspekter på halvfjerdsernes danske teologi. Gyldendal, København 1983. S. 196-208 (o: kapitlet "For menneskelivets skyld. Grundtvig levendegjort ").

Pedersen, A. F. Nørager, Pradikenens idéhistorie. Gyldendal, København 1980. 391 s. [Om Grundtvig, se afsnittet "Vidnesbyrd om Herrens nærvær hos menigheden", s. 305-29.]

Anmeldt af: Søren Nordentoft (Prasteforeningens Blad LXXI 1981, s. 90-93).

Schiøttz-Christensen, Aage, Grasset og bjalken. Trak af den frie tankes vilkår på vejen fra enevalde til folkestyre. Rolv Forlag, København 1982. S. 33-49 ( 0 : kapitlet "Det vitale kompromis"). 
Slumstrup, Finn, "Den utrættelige elsker". I hans: Dobbelte spor. En bog om opror og tradition. En bog om folkehøjskolens opgaver $i$ Danmark. Forfatterforlaget Attika, Valby 1982. S. 16-42.

Stybe, Svend Erik, Dansk idéhistorie. II: Grundbog. Hans Reitzel, København 1981. S. 1013.

Ørsted, Børge, Erindrer De det var $i$ Kongens Have. Hernov, København 1983. S. 81-105. [Optrykt under titlen "På besøg med Grundtvig i Kongens Have nytårsaften 1838" i Ankerkaden. Hilsen fra Holmens Kirke, 60. årg., nr. 4, 1983, s. 4-5.]

\section{Artikler i Tidsskrifter og Samleværker}

Abrahamowitz, Finn, "Grundtvig og friheden". Dansk ungdom og idrat, 85. årg., 1982, nr. 48 , s. $14-15$.

Albeck, Gustav, "Drømmen om skolen i Soer". Grundtvig-Studier 1983, s. 69-86. [Engelsk resumé s. 99-100.]

Albeck-Larsen, Lorentz, "End lever den gamle af dage ... «. Samvirke, 56. årg., 1983, nr. 6-7, s. 13-15.

Andersen, Johannes, "Omkring N. F. S. Grundtvigs liv og levned". Kolt Aldrehøjskole. Årbog 1983, s. 5-12.

Andersen, Richard, "Thyregod". Dansk Udsyn LXIII 1983, s. 256-64. [Om Grundtvigs seks år i Thyregod, samt om forfatteren C. A. Thyregod.]

Balslev-Clausen, Peter, "Guds ord hos Grundtvig belyst ud fra Grundtvig-salmerne i ‘ 46 Salmer. Tillæg til Den danske Salmebog, 1976’ “. Prasteforeningens Blad LXIX 1979, s. 801-09.

Balslev-Clausen, Peter, "I falmede blade, du kølige vind'. Grundtvigs efterårssalme". Vartovbogen 1981, s. 145-61.

Balslev-Clausen, Peter, "Salmerne i skolens sangbøger". Hymnologiske Meddelelser XI 1982, s. 193-292. [Spec. henvises til s. 203, 214, 216, 218 og 230-35.]

Balslev-Clausen, Peter, "'Du, som går ud fra den levende Gud'. En fortolkning ". Grundtvig-Studier 1983, s. 42-68. [Engelsk resumé s. 98-99.]

Balslev-Clausen, Peter, "Salmebog og salmesang. Grundtvigs anmeldelser af Ingemanns Høimesse-Psalmer (1825) og P. A. Fengers udgave af Kingos salmer (1827) «. Hymnologiske Meddelelser XII 1983, s. 3-56.

Balslev-Clausen, Peter, "'Mindes vi en fuldtro ven'. Om en Grundtvig-salmes kirkelige og folkelige sammenhæng ". Hymnologiske Meddelelser XII 1983, s. 151-80.

Balslev-Clausen, Peter, "Det kvindelige som motiv i Grundtvigs 'Sang-Værk' (1837) “. Hymnologiske Meddelelser XII 1983, s. 245-70, og XIII 1984, s. 3-24.

Balslev-Clausen, Peter, "Prædikanten Grundtvig. I anledning af udgivelsen af N. F. S. Grundtvigs prædikener fra årene 1822-1839 og genudgivelsen af hans Sang-Værk bind 1-5". Dansk teologisk Tidsskrift XLVII 1984, s. 43-63.

Balslev-Clausen, Peter \& John Wedell Horsner, "Månedens Grundtvig-salme ". Organistbladet IL 1983. [Tekst-/melodigennemgange ved P. B.-C./J. W. H. s. 99-104/105-09 ("Mindes vi en fuldtro ven "), 137-43/143-48 ("Tag det sorte kors fra graven"), 18389/189-95 ("Kom, Gud Faders Ånd fuldgod"), 243-49/249-54 ("Hyggelig, rolig "), 
273-81/281-88 ("Herren taler: Øer hører!«), 303-11/312-19 (»Trods længselens smerte "), 364-69/369-73 ("Herren han har besøgt sit folk «), 390-95/397-401 ("Døden er den sidste fjende"), 437-47/447-52 ("Skyerne gråner og løvet falder"), 484-94/494-502 ("Rejs op dit hoved, al kristenhed").]

Bjerg, Anne Marie, "Grundtvig och folkligheten". Rallarros 1982, nr. 1-2, s. 5-6. [Dobbeltnummeret ("DK-82", $104 \mathrm{~s}$.) indeholder tekster af/om danske digtere.]

Bjerring-Hansen, Mogens, "Historiefilosofi og antropologi“. Grundtvig-Studier 1980, s. 89-93. [Anm. af Poul Behrendts Viljens former. Augustin - Goethe - Grundtvig, 1974.]

Bording, Aksel, "Grundtvigs betydning for friskolen". Stevnsbogen [Stevns Ungdomsskoles årsskrift] 1983, s. 14-15.

Borgen, Sven, "Grundtvig og u-landene«. Kalejdoskop [udg. af Københavns Dag- og Aftenseminarium], nr. 11, 1984, s. 57-72.

Borum, Poul, "N. F. S. Grundtvig". I: Per Stig Møller (red.), Forfatternes forfatterhistorie. Gyldendal, København 1980. S. 53-63.

Bredsdorff, Morten, "Grundtvig og Sydsjalland". Historisk Samfund for Prostø Amt. Årbog 1983, s. 7-43. [Også separattrykt, cf. ovf. u. II.]

Bredsdorff, Thomas, "Litteraturteori og glossematik». Kritik, nr. 3, 1967, spec. s. 48-55. [Om "Til min egen Meta".]

Brondbjerg, K. F., "En lille mosaik fra mit møde med det grundtvigske». Haslev Seminariums Elevforening. Årskrift 1983, s. 18-32.

Brun, Jens, "Den danske nødvendighed". Vartovbogen 1981, s. 7-20. [Om Grundtvigs myteforståelse og dens stadige aktualitet; cf. Viggo Mortensens anmeldelse af Vartovbogen 1981 i Grundtvig-Studier 1982, s. 86-89.]

Braad, Anne, "Fædrelandssangen". Kursiv. Meddelelser fra Dansklacerforeningen, 1981, nr. $3-4$, s. 20-34, spec. s. 25-27. [Om "Velkommen i den grønne lund ".]

Bugge, K. E., "Lighed i skolen - belyst ud fra den franske revolution, Pestalozzi og Grundtvig “. Dansk Udsyn LIX 1979, s. 200-12, spec. s. 205-09.

Bugge, K. E., "N. F. S. Grundtvig". I: Sven Cedergreen Bech (red.), Dansk biografisk leksikon. V: Frille-Hanssen. Gyldendal, København 1980. S. 318-27. [Ikonografiske oplysninger ved Povl Eller s. 327-28.]

Christensen, Christen, "Grundtvigs opfattelse af folkeligheden og folkelige udtryksformer frem til i dag". Kolt Aldrehøjskole. Arbog 1983, s. 21-32.

Christensen, Frederik, "Grundtvig 1984". Dansk Kirketidende CXXXV 1983, s. 403-07, 419-23. [Foredrag holdt ved Kirkeligt Samfunds årsmøde i Vartov 9.9. 1983; cf. Lars Holms referat smst. s. 319-24.]

Christensen, Johs. H., "Blændværkstimen er nu omme". Levende Billeder IX:3 1983, s. 810; Bogklubben (Gyldendals Bogklubs medlemsblad), nr. 204, september 1983, s. 2425. [Om urpremieren på Til kamp mod dødbideriet med musik af Brødrene Sindssyg (0: Henning Kløvedal Prins og Leif Varmark), samt Erik Grips LP-plade „De levendes land ", 1983 (cf. ndf. u. VI).]

Christensen, Johs. H., "Et Grundtvig-år - over det hele?» Bogens Verden 1983, s. 406-10.

Christiansen, Ole, "Hvad betyder Grundtvig i dag for missionen?" Mission XCIV 1983, s. $115-20$.

Dam, Poul, "En udfordring - også til vor tid“. Uddannelse XVI 1983, s. 465-74.

Dam, Poul, "Grundtvig-bøger i Grundtvigs år". Friskolebladet 1983, s. 232-34 og 300-03, samt 1984, s. 32-33.

Drejergaard, Kresten, "Paulus og Grundtvig". Kredsen XLVI:3-4 1980, s. 32-43. [Foredrag holdt på Grundtvigsk Konvent 1979.] 
Drejergaard, Kresten, "Og ordet blev kød ... Den johannæiske linje hos Luther og Grundtvig ". Prasteforeningens Blad LXXIII 1983, s. 825-34 (spec. s. 831 ff).

Eichberg, Henning, "Wider die innere Kolonisierung. N. F. S. Grundtvig und Friedrich Ludwig Jahn - Sinne, Mythen und volkliche Identität ". I: Kristian Kjær Nielsen \& Finn Slumstrup (red.), Liv og mangfoldighed. Til Poul Engberg på 75 årsdagen 26.5. 1983. Forlaget Mikro, [Århus] 1983. S. 32-45.

Eichberg, Henning, "Imod den indre kolonisering. N. F. S. Grundtvig og Friedrich Ludwig Jahn - sanselighed, myter og folkelig identitet ". Gerlev Idratshøjskole. Arsskrift 1983, s. 9-14; Højskolebladet 1984, s. 292-98. [Dansk oversættelse af den ovennæunte artikel.]

Elbek, Jørgen, "Grundtvig i europæisk åndsliv. Et foredrag". Grundtvig-Studier 1980, s. 7-22.

Elbek, Jørgen, "Grundtvig, Marx og tusindårsriget «. Dansk Udsyn LXI 1981, s. 163-77.

Elbek, Jørgen, "Grundtvigs salmer før Luther. Et foredrag". Grundtvig-Studier 1981, s. 30-46. [Engelsk resumé s. 89.]

Elbek, Jørgen, "Mytologen Grundtvig. Et foredrag". Grundtvig-Studier 1983, s. 29-41.

Engberg, Jytte Grundtvig, "Grundtvig og marinesoldaten". Mål E Male 1982, nr. 4, s. 18-19; Hojskolebladet 1983, s. 521-22.

Engberg, Poul, "Grundtvig-jubelen". Hojskolebladet 1982, s. 749-50.

Engberg, Poul, "Grundtvig og Norden«. Norden og Europa [Snoghø̈j Folkehøjskoles årsskrift] 1983, s. 50-58. [Foredrag holdt ved højskolens 25-års jubilæum.]

Engberg, Poul, "Hvad kom der ud af Grundtvig-året?" Ronshoved Højskoles Aarsskrift 1983, s. 10-15.

Engelbrecht, John, "Ad mærkelige veje til Grundtvig ". Højskolebladet 1983, s. 556-58.

Fain, E. F., "Nationalist Origins of the Folk High School: The Romantic Visions of N. F. S. Grundtvig ". British Journal of Educational Studies XIX 1971, s. 70-90.

Fatum, Poul, "Hvilken betydning har Grundtvig for os i dag?" Stevnsbogen [Stevns Ungdomsskoles årsskrift] 1983, s. 10-13.

Fink, Troels, "Grundtvig og Sønderjylland ". Dansk Udsyn LXIII 1983, s. 305-21.

Folkevirke, 38. årg., nr. 3, september 1983. 32 s. (Tema: "Grundtvig 200«.) [Indhold bl.a.: Ebbe Kløvedal Reich, "Det vældige, beåndede, maniske bjerglandskab - ", s. 45; Doris Ottesen Hansen, "Grundtvigs kvinder", s. 7-15; Erik A. Nielsen, "Hvad en salme er og kan", s. 16-19.]

Frandsen, Kristen Skriver, "Grundtvig-biblioteket «. DF-revy VI 1983, s. 173-74. [Cf. s. 163 og 188.]

Fredsted, Elin, "Nikolaj Frederik Severin Grundtvig (1783-1872)". I: For hundrede år siden: Danmark og Tyskland 1864-1900. Modstandere og naboer, II. Statens Museum for Kunst, København [o. fl.] 1981. S. 88-90. [Efterfulgt, s. 91-92, af et uddrag af Ebbe Kløvedal Reichs Frederik.]

Fredsted, Elin, "Nikolaj Frederik Severin Grundtvig (1783-1872). Ein dänischer Gesellschaftsreformator". I: Vor hundert Jahren: Dänemark und Deutschland 1864-1900. Gegner und Nachbarn. Statens Museum for Kunst, København [o. fl.] 1981. S. 98-101. [Tysk udgave af det ovennævnte skrift.]

Friis, Erik J., "The Grundtvig Bicentennial». The Scandinavian-American Bulletin XXVIII:11 1983, s. 1-2 og 15.

Friis, Kr., "Salmer efterlyses! (En randbemærkning) "/"Guds ord det er vort arvegods". Indre Missions Tidende CXXX 1983, nr. 48, s. 4-6, og nr. 49, s. 4-7 og 20. 
Gleerup, Jørgen, "Grundtvig og den moderne litteratur". Højskolebladet 1982, s. 613-16 og 629-33.

Gleerup, Jørgen, "Kære Grundtvig". Højskolebladet 1983, s. 535-38.

Grell, Birgitte, "Hvad har man forsømt ved ikke at læse Grundtvig?» Vartovbogen 1983, s. 7-21.

Grell, Birgitte, "Grundtvigs ordantropologi og dens placering i en metafysik, der omfatter mere end mennesket ". Fonix VIII 1984, s. 50-60.

Grell, Helge, "Folkelighed - Grundtvigs 'mageløse opdagelse' ". Vartovbogen 1983, s. 5580.

Grosbøll, Jacob, "Alt står i Guds faderhånd. 'Vorherres glæde'". Dansk Kirketidende CXXIX 1977, s. 215-17 og 226-29. [Om Grundtvigs prædiken til 14. søndag e. trin. 1856 og salmen "Vorherres glæde" fra samme år.]

"Grundtvig - læst af ... «. Højskolebladet 1982, s. 246-49 (Kaj Thaning), 276-79 (Torben Damsholt), 294-96 (Christian Thodberg), 309-12 (Svend Bjerg), 341-44 (Hanne Engberg), 373-75 (Ebbe Kløvedal Reich), 405-06 (A. Pontoppidan Thyssen), 437-40 (Christian Thodberg), 453-55 (Kaj Thaning), 503-05 (Torben Damsholt), 532-34 (Svend Bjerg), 598-601 (Johs. H. Christensen), 647-49 (A. Pontoppidan Thyssen), 694-96 (Kaj Thaning), 709-10 (Jørgen Kristensen), 728-32 (Erik A. Nielsen); 1983, s. 9-12 (Torben Damsholt), 24-25 (Jørgen Kristensen m.fl.), 72-74 (Svend Bjerg), 100-02 (A. Pontoppidan Thyssen).

Gudmand-Høyer, T., "I: Grundtvig og historien; II: Grundtvig og myterne; III: Grundtvig og kirkeriget; IV: Grundtvig og trosbekendelsen; V: Grundtvig og naturalisterne; VI: Grundtvig - fortvivlelse og håb; VII: Grundtvig og humaniteten; VIII: Grundtvig og Luther; IX: Grundtvig og den 7. menighed “. Presteforeningens Blad LXXII 1982, s. 905-07, LXXIII 1983, s. 6-9, 99-102, 153-56, 202-05, 333-36, 419-22, 463-66, 533-35. [Cf. til artikel VII: Hans Raun Iversen, "Grundtvig, socialpolitikken og sognemedhjælperordningen ", smst., s. 537-40, med replikker af T. Gudmand-Høyer s. 540-43, Hans Raun Iversen s. 590-92 og T. Gudmand-Høyer s. 645-47.]

Gårdhus, Niels, "Menneske først - kristen så? Incarnationsteologien hos Grundtvig". Prasteforeningens Blad LXVII 1977, s. 633-37.

Hansen, K. R[obert], "Helligtrekongerssalmen“. Indre Missions Tidende CXXIV 1977, s. 25-27. [Om "Dejlig er den himmel blå ".]

Hansen, Knud, "Grundtvigs syn på det menneskelige". Højskolebladet 1982, s. 149-55.

Hansen, Knud, "En bekendelse". Højskolebladet 1983, s. 539-44 og 564-68.

Hansen, Kristian Thule, "Grundtvigs politiske betydning for vor tid". Højskolebladet 1983, s. 561-64.

Hansen, Uffe, "Blomsten og fuglen". Dansk Kirketidende CXXIX 1977, s. 214-15. [Om Grundtvigs brug af billeder fra naturen.]

Harbsmeier, Götz, "Die Bedeutung der Volkssprache in der theologischen Intention N. F. S. Grundtvigs. Elf Thesen ". I: Johann D. Bellmann \& Heinrich Kröger (red.), Sprache, Dialekt und Theologie. Beiträge zur plattdeutschen Verkündigung heute. Vandenhoeck \& Ruprecht, Göttingen 1979. S. 30-37.

Harjunpaa, Toivo, "Grundtvig and His Incomparable Discovery“. The Lutheran Quarterly XXV 1973, s. 54-70.

Hauge, Hans, "Fantasi og fornuft hos Grundtvig". I: Hans Hauge \& Kjeld Holm (red.), $P a ̊$ fortallingens granse. Jubilaumsskrift $i$ anledning af Kredsens 50. årgang, 1983 [= Kredsen, 50. årg., nr. 1-2, 1983]. S. 99-107. 
Hauge, Hans, "Grundtvig og fantasien ". Dansk Kirketidende CXXXV 1983, s. 264-66.

Heide, Paul, "Grundtvigs salmer og sange i skolen". Kalejdoskop [udg. af Københavns Dag- og Aftenseminarium], nr. 11, 1984, s. 74-97.

Heinemeier, Erik, "Løgstrup som Grundtvigs arvtager?" Religion. Idé og debat 1983, nr. 5, s. 3-8.

Henningsen, Hans, "Folkelighed og græsrodsbevægelser - belyst i forhold til Grundtvig". Religion. Idé og debat 1983, nr. 5, s. 9-15. [Foredrag holdt ved kursus for seminariernes religions- og pædagogiklærere 21.-24.2. 1983.]

Herman, Ruth Thorup, "The Educational Philosophy of N. F. S. Grundtvig. A Century of Influence. A Case Study of a Lutheran Congregation, Omaha, Nebraska ". The Bridge. Journal of the Danish American Heritage Society III:2 1980, s. 65-82.

Holm, Kjeld, "Forkyndelse først". I: Hans Hauge \& Kjeld Holm (red.), På fortallingens granse. Jubilaumsskrift $i$ anledning af Kredsens 50. årgang, 1983 [= Kredsen, 50. årg., nr. 12, 1983]. S. 17-26. spec. s. $21 \mathrm{ff}$.

Holm, Lars, "1825, 1832, 1983». Dansk Kirketidende CXXXV 1983, s. 215-19. [Om Grundtvig-udgivelser.]

Honoré, Johs., "Om at holde skole med Luther og Grundtvig i bagagen". Haslev Seminariums Elevforening. Årsskrift 1983, s. 42-46.

Horsner, John Wedell, "Grundtvig and Music". Musical Denmark, nr. 34, 1983, s. 2-4.

Hvidt, Kristian, "Portræt af en 200 -årig. N. F. S. Grundtvig skildret af en udlænding". Nordisk tidskrift for vetenskap, konst och industri LIX 1983, s. 274-78. [Om Edmund Gosses Grundtvig-omtale i Two Visits to Denmark, 1911, aftrykt s. 276-78 efter oversættelsen fra 1912.]

Haarder, Bertel, "Mellem hundeklogskab og flovt kæleri". Ronshoved Højskoles Aarsskrift 1983, s. 4-9. [Festtale holdt ved Aarhus Universitets årsfest 1983; også trykt i JyllandsPosten 17.9. 1983.]

Iversen, Hans, "Grundtvigs inkarnatoriske kristendomssyn". Dansk teologisk Tidsskrift XLIV 1981, s. 258-77.

Iversen, Hans, "Erfaringskvalitet og kristen tolkning hos Grundtvig". Kritisk forum for praktisk teologi, nr. 9, 1982, s. 133-43.

Iversen, Hans, "Grundtvig som inspiration til mission". Mission XCIV 1983, s. 94-115.

Iversen, Hans Raun, "Noter om Grundtvigs menighedserfaring". Kritisk forum for praktisk teologi, nr. 14, 1983, s. 19-26.

Jensen, Gunnar, "Grundtvigs skoletanker og folkeskolen i dag". Fyens Stiftsbog 1983, s. 27-34.

Jensen, Henrik Fibæk, "Grundtvigs erkendelsesteori. Om forholdet mellem tro og fornuft i tidsskriftet 'Danne-Virke' (1816-19) «. Grundtvig-Studier 1979, s. 29-65. [Engelsk resumé s. 94-97.]

Jensen, Jørgen I., "Luther og Grundtvig - et oplæg". Dansk Kirkeliv 1983-1984, 1983, s. 31-65.

Jensen, Jørgen I., "Grundtvig og nutidens problemer med historien ". Københavns Universitets Almanak. Skriv- og Rejse-Kalender (...) 1984, 1983, s. 119-27.

Jensen, Ketty Lykke, "Grundtvig og Falster". Lolland-Falsters historiske Samfund. Årbog 1983, s. 17-25.

Jepsen, Holger, "'Nyaars-Morgen' i fugleperspektiv ". Århus Stift XXI 1983, s. 29-43.

Jessen, Carl Chr., Karsten Nissen \& Knud Ochsner (red.), Til alle folkeslag ... Mission og folkelighed. DMS-forlag, Hellerup 1977. 68 s. (Nyt Synspunkt, nr. 5.) [Indhold bl.a.: 
Regin Prenter, "Mission og folkelighed", s. 7-19, spec. s. 8-13; Ellen Laursen, "Folkelighed og mission - set fra Santalmissionens arbejdsfelt «, s. 33-43, spec. s. 35-37; Knud Ochsner, "Til alle - alle folkeslag", s. 57-61, spec. s. 57-59.]

Jessen, Peter Neergaard, "Hvad har Grundtvig at sige os i dag?" Dansk Kirketidende CXXVIII 1976, s. 392-95 og 408-11.

Johansen, Albert, "End lever den gamle af dage". Folkeskolen C 1983, s. 1324-27.

Jørgensen, Aage, "Grundtvig-litteratur 1974-1978«. Grundtvig-Studier 1979, s. 77-87.

Kampp-Olsen, Otto, "Grundtvig som salme- og sangskriver". Dansk ungdom og idrat, 85. årg., 1982, nr. 48, s. 22-23.

Kelstrup, Hans, "Modersmålet er forudsætningen for ansvarliggørelse af folket ". Dansk ungdom og idrat, 85. årg., 1982, nr. 48, s. 20-21.

Klonteig, Olav, "Grundtvig og Freire". Folkehøgskolen LXXV 1979, s. 1-5.

Klonteig, Olav, "Grundtvigs menneskesyn". Folkehogskolen LXXVIII 1982, s. 140-43; Folkhögskolan 1982, s. 57-60; Kristen folkehogskole 1982, nr. 7, s. 11-13; Kansanopisto 1983, nr. 5, s. 15-20 (på norsk og i finsk oversættelse).

Klonteig, Olav, "Grundtvig i dagens pedagogiske situasjon". Folkehogskolen LXXIX 1983 , s. 143-45.

Klonteig, Olav, "Grundtvig og vår tids folkeopplysning ". Studienytt 1983, nr. 6, s. 16-18.

Kofoed, Niels, "Grundtvig som mytolog og historiker". Kalejdoskop [udg. af Københavns Dag- og Aftenseminarium], nr. 11, 1984, s. 5-35.

Kruse-Blinkenberg, Lars, "From og fromhed - et bidrag til dansk betydningslære". Acta Philologica Scandinavica XXXII 1979, s. 129-95, spec. s. 178-81.

Kuhn, Hans, "A Christian Dawn-Song from Scandinavia". Parergon. Bulletin of the Australian and New Zealand Association for Medieval and Renaissance Studies, nr. 14, 1976, s. 3-22. [Spec. om Grundtvigs gendigtning af dagvisen, "Den signede Dag", s. 16-22.]

Kaalø, Sten, "Grundtvigs sangværk". Højskolebladet 1983, s. 558-60.

Larsen, Ejvind, "Gjer det sjølv! Grundtvig og vi“. Syn og Segn LXXXIX 1983, s. 450-59.

Larsen, Ejvind, "Kæmpeånden og maskineriet - og kvinden. Grundtvig og den moderne teknik - og Clara Bolton". Ingenioren IX:40, 7.10. 1983, sektion 1, s. 14-15.

Larsen, Svend Erik, [Anm. af Gustav Albeck (udg.), Dag- og Udtogsbøger, I-II, 1979.] Scandinavica XX 1981, s. 225-26.

Lindboe, Ole, "Det Levende Ords Abracadabra fejres ved sin 200-års fødselsdag ". Forskningen E Samfundet IX:2 1983, s. 3-4. [Om Grundtvig-forskningen på Københavns Universitet.]

Lindhardt, P. G., "Konfrontation. Duellen mellem Grundtvig og Kierkegaard". Aalborg Stiftsbog 1982, s. 11-26.

Lindhardt, P. G., "Grundtvigs syn på kirketugt «. Dansk Kirkeliv 1983-1984, 1983, s. 6679.

Lindhardt, P. G., "Mennesket og teologen Grundtvig". Danmarksposten LXIV:5 1983, s. 4-7.

Lundgreen-Nielsen, Flemming (medd.), "'Odin og Saga' genfundet. En Grundtvig-tekst fra 1810«. Grundtvig-Studier 1979, s. 10-16. [Subskriptionsindbydelse signeret af Grundtvig og F. C. Sibbern.]

Lundgreen-Nielsen, Flemming, "'Rød og hvid i Billedsalen'. Grundtvigs døds- og mindedigte [I-II]". Grundtvig-Studier 1980, s. 23-60, og 1981, s. 47-83.

Lundgreen-Nielsen, Flemming, "N. F. S. Grundtvigs Auffassung der nordischen Mythen in seiner Forschung und Dichtung ". I: Klaus Bohnen, Sven-Aage Jørgensen \& 
Friedrich Schmöe (udg.), Dänische 'Guldalder'-Literatur und Goethezeit. Wilhelm Fink Verlag, Kopenhagen/München 1982. S. 160-91. (Text \& Kontext, Sonderreihe, 14.)

Lundgreen-Nielsen, Flemming, "N. F. S. Grundtvigs 'Langt høiere Bjerge' «. I: Henrik Glahn, m. fl. (red.), Hvad Fatter gjor ... Boghistoriske, litterare og musikalske essays tilegnet Erik Dal. Poul Kristensen, Herning 1982. S. 289-307.

Lundgreen-Nielsen, Flemming, "Grundtvig og Det litterære Selskab 1805-1822«. Grundtvig-Studier 1982, s. 63-73.

Meibom, Aksel, „Post festum“. Vesterlund Ungdomsskole. Årbog 1983, s. 14-18.

Michelsen, William, "Grundtvig og hans samtids tænkemåde. Overvejelser over Grundtvigs stilling i dansk åndsliv «. Grundtvig-Studier 1979, s. 17-28. [Engelsk resumé s. 92-94.]

Michelsen, William, "Sin samtids kritiker. N. F. S. Grundtvig 1783-1872«. GrundtvigStudier 1983, s. 7-28. [Engelsk resumé s. 94-97.]

Michelsen, William, "Hvad var Grundtvigs kulturprogram?» Bogens Verden 1983, s. 41315. [Rettelser hertil s. 540.]

Mortensen, Enok, "Grundtvig's Influence on American Education". The Bridge. Journal of the Danish American Heritage Society VI:1 1983, s. 80-94. [Foredrag holdt ved Grundtvig-seminar i Holte 17.6. 1983.]

Mortensen, Karen Marie, "Hekseri og kærlighed". Vartovbogen 1983, s. 22-39. [Om Grundtvig, kvinderne og vor tid.]

Mortensen, Karen Marie, "Poetisk videnskab - et forsøg på en samtale mellem Grundtvig og nogle moderne tyske tænkere". Fønix VI 1982, s. 201-18. [Om "Om Nordens videnskabelige Forening " i relation til Hans-Georg Gadamer, Jürgen Habermas og Helmut Peukert.]

"Månedens salme". Dansk Kirkesangs årsskrift 1979-80, 1981, s. 51-155. [En gennemgang af 30 salmer og deres melodier. Salmerne, bl.a. 3 af Kingo, 2 af Brorson, 1 af Wexels, 10 af Grundtvig og 6 af Aastrup, gennemgås af Olav Andersen, Gunnar Pedersen og Christian Thodberg. Talen er om følgende Grundtvig-salmer: "Blomstre som en rosengård ", s. 59-60 (CT); "Dig rummer ej himle", s. 69-71 (OA); "Gud Helligånd, vor trøstermand ", s. 79-83 (CT); "Herren af søvne opvågned, opsprang", s. 88-90 (OA); "Herren han har besøgt sit folk", s. 92-94 (OA); "Herrens røst var over vandet", s. 9598 (CT); "Hil dig, frelser og forsoner", s. 104-06 (OA); "Hør vor helligaftens bøn", s. 110-12 (GP); "Kom, Gud Helligånd, kom brat", s. 119-20 (GP); "Med sin alabasterkrukke", s. 126-28 (CT). Melodierne gennemgås af Henrik Glahn, Torben Schousboe og Søren Sørensen.] [Oprindelig trykt i Dansk Kirkemusiker Tidende LXXIV-LXXVI 1978-80.]

Nielsen, Erik A., "En dråbe stærk. Om Grundtvigs 'Paaske-Lilien'". I: Henrik Glahn, m.fl. (red.), Hvad Fatter gjor ... Boghistoriske, littercere og musikalske essays tilegnet Erik Dal. Poul Kristensen, Herning 1982. S. 334-50.

Nielsen, Erik A., "Hjertets søde morgendrøm “. Dansk Kirkeliv 1983-1984, 1983, s. 8088.

Nielsen, Erik A., "Grundtvigs humor". Forskningen E Samfundet IX:5 1983, s. 7-11.

Nielsen, Helge Baden, "På tærsklen til et Grundtvig-år". Meddelelser fra Århus Stift XX . 1982, s. $19-30$.

Nielsen, Vilhelm, "Om at læse Grundtvig ". Højskolebladet 1980, s. 7-13; Folkehøgskolen LXXVII 1981, s. 1 og 3-8.

Nielsen, Vilhelm, "Grundtvig og sproget«. Højskolebladet 1983, s. 546-49. 
Nielsen, Åge, "Grundtvig i sange og salmer ". Dansk Sang XXXV 1983-84, nr. 2, s. 1214 , nr. 3, s. $38-40$ og 42 , nr. 4 , s. $10-13$, og nr. 5, s. 30-34.

Noack, Bent, "Baggrunden for salmen 'Kommer, sjæle dyrekøbte - '". Dansk Kirkesangs årskrift 1981-82, 1982, s. 83-99.

Noack, Bent, "'Om Himmerigs Rige'. Et par bemærkninger til nr. 658". Hymnologiske Meddelelser XIII 1984, s. 25-37. [Om Grundtvigs fra Den danske Salmebog kendte redaktion af den i Hans Thomissøns salmebog oprindeligt offentliggjorte salme, s. 2936.]

Noe-Nygaard, Helge, "Grundtvigs historiske kirkesyn". Vartovbogen 1980, s. 102-21.

Ny politik XIV:2 1983. Tema: "Grundtvig", s. 8-14. [Hans Sølvhøj, "Grundtvig i det verdslige samfund ", s. 8-9; Anker Jørgensen, "Grundtvigs påvirkning af samfundsudviklingen ", s. 9-10; Bent Greve, "Vi har brug for en ny Luther, Grundtvig eller Marx", s. 10-11; Søren Nørgaard Nielsen, "Mod snæversyn og kirketugt", s. 11-12; K. B. Andersen, "Der er meget at hente hos Grundtvig ", s. 13-14.]

Nørby, Ejvind, "Det grundtvigske og læreruddannelsen. For sammenhængens skyld". Haslev Seminariums Elevforening. Årskrift 1983, s. 33-40.

Nørfelt, Henrik Fibiger, "N. F. S. Grundtvig 1783-1983«. Hymnologiske Meddelelser XII 1983, s. 123-28 og 191-94. [Om otte ret upåagtede melodier - aftrykt foran artiklens to dele - til Grundtvig-tekster.]

Nørgaard, Helmer, "Musik til Grundtvig". Kalejdoskop [udg. af Københavns Dag- og Aftenseminarium], nr. 11, 1984, s. 98-117 (+ bilag s. 118-34).

Nørr, Erik, "Tvangsforflyttelse af kapellaner. Da tjenstledig kapellan N. F. S. Grundtvig skulle være præst og skolelærer på Manø". Kirkehistoriske Samlinger 1982, s. 51-59.

Overgård, Frands Ove, "Noget om folkelighed". Kolt Aldrehøjskole. Arrbog 1983, s. 3342.

Paul, Fritz, "Romantik und poetischer Realismus". I: Fritz Paul (red.), Grundzüge der neueren skandinavischen Literaturen. Wissenschaftliche Buchgesellschaft, Darmstadt 1982. Spec. s. 94-96.

Pedersen, Edvard Wulff, "Evangeliet som sprænger grænser". Mission XCIV 1983, s. $121-26$.

Pedersen, Jørgen, "Den dybe sammenhæng. Om Grundtvigs salme 'Hil dig, Frelser og Forsoner' som gengivelse af den cisterciensiske 'Salve, mundi salutare' set på baggrund af hans forhold til den middelalderlige hymnedigtning ". Hymnologiske Meddelelser XII 1983, s. 194-239. [English Summary, s. 237-39.]

Petersen, Flemming, "Om Grundtvig og hans højskoletanker". Ungdomshøjskolen ved Ribe. Aarbog 1983, s. 70-78.

Petersen, Kr. Schultz, "Grundtvig og Vølven«. Krabbesholm Højskole 1983, s. 5-18.

Plekon, Michael, "N. F. S. Grundtvig: Renewer of the Church ". Lutheran Forum XVII:4 1983, s. 8-11.

Prenter, Regin, "Han sang Israels Gud salmer"/»En mageløs opdagelse». Indre Missions Tidende CXXX 1983, nr. 29, s. 3-5, og nr. 30, s. 3-5.

Ransby, Erik, "Folkesang og kirkesang. Noget om Laub og Grundtvig". Prasteforeningens Blad LXXIII 1983, s. 513-22. [Hertil: John Wedell Horsner, smst., s. 592-95, med replikker af Erik Ransby s. 641-45 og John Wedell Horsner s. 720-22.]

Rasmussen, Børge, "En jule-sangs tilblivelse". Indre Missions Tidende CXXIV 1977, s. 1110-11. [Om "Jule-Aften! Du er skøn «.]

Rasmussen, Ole C., "Grundtvig og folkeligheden“. Dansk ungdom og idrat, 85. årg., 1983, nr. 48 , s. $8-9$. 
Rasmussen, Ole C., "Menneske først, kristen så ". Dansk ungdom og idrat, 85. årg., 1983, nr. 48 , s. $12-13$.

Reich, Ebbe Kløvedal, „Fra kristentro og kvinder ... Om kvinderne i N. F. S. Grundtvigs liv «. Gutenberghus årsskrift 1983, s. 44-49.

Reich, Ebbe Kløvedal, "Grundtvigs arv til os: Forjættelsen om hjertets vovemod ". Stiftsbog og landemode-akt for Lolland-Falsters stift 1983, s. 20-32. [Foredrag holdt ved 200årsfesten i Udby præstegård 11.9. 1983.]

Rydal, Ole, "Menneske først - og sidst! Om ny-grundtvigianismen". Tidehverv LVIII 1984, s. 43-49.

Sandstrøm, Bjarne, "Portrætdigtet «. Kursiv. Meddelelser fra Dansklarerforeningen 1981, nr. 3-4, s. 35-65, spec. s. 52-55. [Om "Jørgen Sorterup".]

Sandvik, Sigurd, "Grundtvig til minne". Kirke og Kultur LXXXVIII 1983, s. 419-26.

Scheile, Hermann, "N. F. S. Grundtvigs Aussagen zur Erwachsenenbildung in Heimvolkshochschulen - Bedeutungen in Geschichte und Gegenwart ". I: F. Schmidt (red.), Die ländliche Heimvolkshochschule, Folge 6: Beiträge zur Erwachsenenbildung. Verband Ländlicher Heimvolkshochschulen Deutschlands, Stuttgart 1984. S. 18-34. [Foredrag holdt 26.10. 1983; diskussionsresumé s. 35-36.]

Scheile, Hermann, "Vater der Volkshochschulen. N. F. S. Grundtvig zum 200. Geburtstag ". Nachrichten der evangelisch-lutherischen Kirche in Bayern 1983, s. 350-52.

Schmidt, Bodil, "Videnskab og hverdagssprog. Grundtvigs betragtning af modersmålet $i$ teori og praksis, belyst ved hans afhandling 'Om Ordsprog', 1817 «. Grundtvig-Studier 1980, s. 61-85.

Siebert, Horst, "Aktuelles über Grundtvig ". Literatur- und Forschungsreport Weiterbildung, nr. 12, 1983, s. 3-7. [Om to Grundtvig-udgivelser.]

Simon, Erica, "Den grundtvigske folkelighed - før og nu". Dansk Udsyn LXIII 1983, s. 267-90.

Simon, Erica, "Grundtvig som kultureksport-vare 1983«. Danmarksposten LXIV:5 1983, s. 8-9.

Skjerbæk, Thorkild, "Gartneren og herskabet". Højskolebladet 1984, s. 232-35 og 246-52. [Bl. a. om Henrik Pontoppidans opgør med Grundtvig.]

Skovmand, Roar (medd.), "Grundtvigs sønner og 'den sorte skole' ". Arbog for dansk Skolehistorie XIV 1980, s. 152-54. [Brev af 22.3. 1927 fra Stener Grundtvig til Helge Skovmand.]

Slumstrup, Finn, "Kernebegreber i Grundtvigs oplysningstanker". Haslev Seminariums Elevforening. Årsskrift 1983, s. 5-17.

Stenbæk, Jørgen, "Stat og kirke i Danmark «. Prasteforeningens Blad LXXIII 1983, s. 10918 , spec. s. $112-14$.

Stenstrup, Ingemann, "Grundtvigs barndom og ungdom". Vesterlund Ungdomsskole. Årbog 1983, s. 4-11. [Årbogen indeholder tillige fem svar på spørgsmålet "Hvad kan Grundtvig sige en lærer i dag? "]

Sveidahl, Erik, "Om Grundtvigs pædagogiske tanker ". Kalejdoskop [udg. af Københavns Dag- og Aftenseminarium], nr. 11, 1984, s. 37-56.

Sølvbjerg, Knud, "Antropologi og poetik i 'Verdens Krønike' 1814«. Grundtvig-Studier 1982, s. 46-62. [Udsnit af specialeafhandling (skrevet i 1976), præsenteret af William Michelsen; engelsk resumé s. 93-94.]

Terp, Chr. Ulrich, "Den grundtvigske nødvendighed «. Vartovbogen 1983, s. 81-95.

Thaning, Kaj, [Anm. af Grundtvig och folkupplysningen ..., Kungälv 1978; cf. GrundtvigStudier 1979, s. 78.] Hojskolebladet 1979, s. 147-50. 
Thaning, Kaj, "Grundtvigs gennembrud som forfatter". Hojskolebladet 1980, s. 341-44. [Anm. af Gustav Albeck (udg.), N. F. S. Grundtvigs Dag- og Udtogsbøger, I-II, 1979.]

Thaning, Kaj, "Den 'mageløse opdagelse's tilblivelse". Grundtvig-Studier 1981, s. 7-29. [Engelsk resumé s. 86-88.]

Thaning, Kaj, "Prædikenen 31.7.1825 og dens hidtil utrykte slutning". Grundtvig-Studier 1982, s. 17-19. [Prædikenen er aftrykt s. 7-16.]

Thaning, Kaj, "Menneske først og kristen så -«. Presteforeningens Blad LXXIII 1983, s. 601-07. [Tale holdt på det nordiske højskolemøde, Askov 5.8. 1983.]

Thill, Georges, "Education populaire. Voyage au pays des 'højskoler' ". La revue nouvelle LXXVII 1983, s. 185-92. [Sammenfatning af et kursus, "Education permanente, cultures et technologies", afholdt på Askov Højskole 25.5.-3.6. 1982; herfra foreligger en duplikeret rapport, 155 s., udg. af Facultés Universitaires de Namur, - hvori adskilligt om Grundtvig.]

Thodberg, Christian, "Om 'Gud Helligånd, vor trøstermand'". I: Bent Hahn, m. fl. (red.), Humanitet og eksistens - en artikelsamling tilegnet Borge Diderichsen. Gyldendal, København 1976. S. 24-37.

Thodberg, Christian, "Grundtvig som salmedigter". Kirke og Kultur LXXXVIII 1983, s. 386-418. ["... fremgået af en gæsteforelæsning på Oslo Universitet $i$ april 1983 ... en let bearbejdet udgave af en artikel fra ... N. F. S. Grundtvig. Tradition and Renewal ... 4 .]

Thodberg, Christian, [Anm. af Gustav Albeck (udg.), N. F. S. Grundtvigs Dag- og Udtogsboger, I-II, 1979.] Grundtvig-Studier 1980, s. 86-88.

Thyssen, Anders Pontoppidan, "Grundtvigs kultursyn og det pluralistiske samfund". Fonix V 1981, s. 1-18.

Thyssen, A. Pontoppidan, "Om tilblivelsen af Grundtvigs kirkeforståelse". Haderslev Stiftsbog 1981, s. 18-32; Kritisk forum for praktisk teologi, nr. 14, 1983, s. 5-18.

Thyssen, A. Pontoppidan, "Det levende ord i kirken. En hovedlinje i Grundtvigs kirkeforståelse". Prasteforeningens Blad LXXIV 1984, s. 133-38.

Toft, Tage, "Folkets egne gamle ord ". Kolt Aldrehøjskole. Årbog 1983, s. 13-20.

Vartovbogen 1982-1983. Kirkeligt Samfunds Forlag, København 1982-83. 119 og 153 s.

1982) Anmeldt af: Viggo Mortensen (Grundtvig-Studier 1983, s. 90-92).

1983) Anmeldt af: Kristian Bundgård (Dansk Kirketidende CXXXV 1983, s. 342-44),

Ketty Jensen (Kolding Folkeblad 24.9. 1983), Aage Jørgensen (Højskolebladet 1983, s. 733).

Vinther, Elna, "N. F. S. Grundtvigs missionssyn". Mission XCIV 1983, s. 127-40.

Warming, Per, "Landet er elsket - om Grundtvig og fremtidens højskolesangbog". I: Kristian Kjær Nielsen \& Finn Slumstrup (red.), Liv og mangfoldighed. Til Poul Engberg på 75 årsdagen 26.5. 1983. Forlaget Mikro, [Århus] 1983. S. 26-31.

Wind, H. C., "Dansk kultur i dag i lyset af Kierkegaard og Grundtvig". Testrup Højskole 1983, s. 22-35.

Wisti, Folmer, "Grundtvig ud over grænserne». Dansk Udsyn LXIII 1983, s. 33-48.

Yde, Henrik, "Grundtvig og dansk socialisme". Krabbesholm Højskole 1983, s. 19-34.

Aagaard, Johannes, "Grundtvigs og grundtvigsk missionsforståelse og missionspraksis, kritisk vurderet". Mission XCIV 1983, s. 142-84. 


\section{Avisartikler}

Akerlie, Olav, "Grundtvig og Norge". Kristeligt Dagblad 17.9. 1983.

Andersen, Hans, "Grundtvig lærte os at synge". Jyllands-Posten 11.9. 1983.

Andersen, K. B., "Livet forplantes ikke ved døde sild". Berlingske Tidende 11.9. 1983.

Andreasen, Victor, "Vort nationale tågehorn". Ekstra-Bladet 17.9. 1983. [Optrykt i Højskolebladet 1983, s. 604.]

Barfod, Birgit, "Grundtvigs julebudskab". Jydske Tidende 24.12. 1981. [Om "Et Barn er født i Betlehem".]

Beck, Lis, "Lise - Marie og Asta «. Dagbladet 6.9. 1983.

Bertelsen, Ole, "Grundtvig, nødvendig - nu". Weekendavisen 23.9. 1983.

Boch, Erik, "Hvad Danmark har brug for: Grundtvig nemlig ". B. T. 8.9. 1983.

Brandes, Edvard, "Den eneste der dannede skole". Politiken 3.9. 1983. [Oprindelig offentliggjort i Morgenbladet 9.9. 1883.]

Bredsdorff, Morten, "Grundtvigianismen følte Albertis fald". Frederiksborg Amts Avis 9.9. 1983.

Brondbjerg, K. F., "Menneske først og kristen så “. Kristeligt Dagblad 13.9. 1983.

Burmeister, Svend, "Tillykke Frederik«. Berlingske Tidende 4.9. 1983. [ $\AA$ bent brev fra Verdensbankens direktør til Grundtvig.]

Børge, Vagn A[lbeck], "Grundtvigs dagbøger". Frederiksborg Amts Avis 1.5. 1980.

Christensen, Dan, "Tillykke med patriarken". Holbak Amts Venstreblad 7.9. 1983. [Om Grundtvig og folkeoplysningen.]

Christensen, Dan Ch., "Grundtvig går igen i Sorø 1950«. Politiken 2.9. 1983. [En dialog mellem en moderne uforknyt højskoleelev og den genopstandne Grundtvig om livet på en højskole omkring 1950; dialogen, skrevet 1837-38, offentliggøres smst. som kronik.]

Christensen, Johs. H., "Hvasse spyd, indviklede i bomuld “. Kristeligt Dagblad 15.8. 1983. [Om tidsskriftet "Danne-Virke".]

Christensen, Johs. H., "Vejen til Vartov". Kristeligt Dagblad 13.7. 1984.

Dahl, Kurt, "Efter festen for Grundtvig “. Land og Folk 17.9. 1983. [Bl. a. om nogle af 200-årets Grundtvig-udgivelser.]

Dam, Poul, "Grundtvig - en hedensk slagsbroder". Aktuelt 16.2. 1983.

Dam, Poul, "Grundtvig til daglig brug ". Jyllands-Posten 8.9. 1983. [Debat: Henning Tjørnehøj 27.9. 1983, Poul Dam 3.10. 1983 og Henning Tjørnehøj 12.10. 1983.]

Dam, Poul, "Grundtvig - en politiker «. Kristeligt Dagblad 2.9. 1983.

Dam, Poul, "Kernen hos Grundtvig". Berlingske Tidende 4.9. 1983.

Dissing, Søren, "Grundtvigs ærinde". Vendsyssel Tidende 4.9. 1983.

Drejergaard, Kresten, "Hvor blev grundtvigianerne egentlig af?" Kristeligt Dagblad 15.9. 1983.

Eller, Povl, "Eckersberg og Grundtvig". Politiken 7.9. 1983.

Engberg, Poul, "Løfterige fornyelser på grundtvigske højskoler«. Kristeligt Dagblad 5.9. 1983.

Eriksen, Herluf, "Vigtigt at kæmpe mod døden før døden«. Kristeligt Dagblad 9.9. 1983. [Prædiken holdt i Grundtvigskirken 8.9. 1983.]

Fosmark, Johs., "Grundtvigianerne og Indre Mission". Jydske Tidende 14.9. 1983. 
Gjesing, [Knud] Bjarne, "Smørklatten Danmark «. Fyens Stiftstidende 15.8. 1980. [Om digtet "Dansk Ravne-Galder".]

Greve, Ejnar, "Kvindernes plads i Grundtvigs digtning ". Kristeligt Dagblad 8.1. 1981.

Grønnegaard, Aage, "Grundtvigs erfaringer i barndomsårene kom til at præge ham dybt ". Horsens Folkeblad 3.8. 1983.

Hansen, H. P., "Grundtvig, pinsens store sanger ". Frederiksborg Amts Avis 25.5. 1980.

Hansen, H. P., "Den unge Grundtvig og Udby præstegård". Frederiksborg Amts Avis 28.7. 1983.

Hansen, H. P., "Kirkesang som vinger højt over det jordiske". Frederiksborg Amts Avis 7.9. 1983.

Hansen, Kristian Thule, "Grundtvig og folkeligheden “. Kristeligt Dagblad 31.8. 1983.

Haystrup, Helge, "N. F. S. Grundtvigs veje og livsmål". Jydske Tidende 4.9. 1983.

Haystrup, Helge, "Tro som fællesskab og tryghed i Gud". Jydske Tidende 18.9. 1983.

Havgaard, Hasse, "Ham den grimme Grundtvig". Politiken 17.9. 1983.

Hededal, Eline, "Wartenweiler og Grundtvig ". Dagbladet 7.9. 1983.

Hein, Niels, "Da 'Den signede Dag' blev forbudt “. Politiken 6.6. 1976.

Holmberg, Hans, "Grundtvigs børn lærte græsk før den lille tabel". Flensborg Avis 4.5. 1983.

Holmberg, Hans, "De vildeste rejser gik til hans indre". Fredericia Dagblad 1.8. 1983; Dagbladet 2.8. 1983; Flensborg Avis 10.8. 1983; Herning Folkeblad 27.8. 1983; Frederiksborg Amts Avis 28.8. 1983.

Honoré, Paul, "Han er ikke til at komme udenom ". Fyens Stiftstidende 25.9. 1983.

Husted, Henny Lomholt, "Grundtvigs og Kolds skoletanker i dag". Vestkysten 5.10. 1981.

Høgh, Jon, "Grundtvigs folkerejsning [efter Danmarks fallit i 1813]“. Vendsyssel Tidende 30.1. 1981; Flensborg Avis 17.2. 1981; Vestkysten 24.3. 1981.

Haarder, Andreas, "Kæmpeliv i nord ". Kristeligt Dagblad 21.10. 1983.

Haarder, Bertel, "Frihed til åndelig vækst det vigtigste". Frederiksborg Amts Avis 8.9. 1983.

Haarder, Bertel, "Vi er sandelig ikke færdig med Grundtvig". Dagbladet 10.9. 1983; Nastved Tidende 10.9. 1983; Vejle Amts Folkeblad 10.9. 1983; Vestkysten 10.9. 1983; Midtjyllands Avis 12.9. 1983; Kolding Folkeblad 13.9. 1983; Sjallands Tidende 13.9. 1983; Flensborg Avis 14.9. 1983; Morsø Folkeblad 14.9. 1983; Vendsyssel Tidende 15.9. 1983; Horsens Folkeblad 17.9. 1983; Bornholms Tidende 28.9. 1983.

Information 8.9. 1983. ["Grundtvig ", forsideleder af el, o: Ejvind Larsen; Viggo Mortensen, "Grundtvig i vore hjerter ", om en række bøger; id., "Syv teser - om forståelsen af Grundtvigs udtryk 'menneske først og kristen så" "; Carsten Jensen, "Grundtvig i blodfattig-firserne", om to bøger; Ejvind Larsen, "Du lukked op med dine nøgler for alt - fra præst til gøgler", om to bøger.]

Jansen, Flemming, "Ind til computeren med Grundtvig i rygsækken ". Vendsyssel Tidende 8.9. 1983.

Jensen, Bo Green, "De levendes land ". Weekendavisen 2.9. 1983. [Debat: Niels Bach 16.9. 1983.]

Jensen, Bo Green, "Billeder på færden: Grundtvigiana II". Weekendavisen 23.12. 1983. [Om en række jubilæumsudgivelser.]

Jensen, Ole, "Om Grundtvig og gudstjenesten". Fyens Stiftstidende 7.9. 1983; Aalborg Stiftstidende 7.9. 1983. 
Jespersen, Per, "Grundtvig og fremtiden". Jydske Tidende 9.1. 1983.

Jor, Finn, "Marxister må godta Grundtvig ". Aftenposten 8.9. 1983.

Jørgensen, Anker, "Grundtvig har sin del af æren ". Fyens Stiftstidende 26.3. 1983; Aalborg Stiftstidende 27.3. 1983; Arhuus Stiftstidende 27.3. 1983. [Om dansk arbejderbevægelses gæld til Grundtvig - og omvendt.]

Kampp-Olsen, Otto, "Grundtvigs sange". Flensborg Avis 30.10. 1982; Frederiksborg Amts Avis 14.11. 1982; Aalborg Stiftstidende 28.8. 1983.

Kaufmann, Hanne, "Nu går Grundtvig gennem Europa". Kolding Folkeblad 9.8. 1983; Nestved Tidende 12.8. 1983. [Om Grundtvig og Norbert Lochner.]

Kemp, Peter, "Grundtvigiana. Nyudgivelser i jubelåret ". Politiken 27.8. 1983.

Kemp, Peter, "Det levende ord på dataskærmen". Politiken 5.9. 1983.

Kemp, Peter, "Filosofferne og Grundtvig". Politiken 7.9. 1983. [I anledning af den filosofiske Grundtvig-kongres på Københavns Universitet 9.-10.9. 1983.]

Kiilerich, Povl, "Grundtvigs livsværk mindet". Horsens Folkeblad 9.9. 1983; Kristeligt Dagblad 9.9. 1983; Vestkysten 9.9. 1983. [Tale holdt på Vartov.]

Kistrup, Jens, "Den levende Grundtvig". Berlingske Tidende 8.9. 1983.

Kjølbye, Bente, "Julens salmer". Berlingske Tidende 24.12. 1979.

Klejst, Johan, "Tre nye Grundtvigbøger". Holbaek Amts Venstreblad 24.9. 1983.

Klejst, Johan, "Fra almue til folk ". Aktuelt 30.8. 1983.

[Knudsen,] Helle Bygum, "Socialisten og liberalisten Grundtvig". Berlingske Tidende 4.9. 1983. [Samtale med Ejvind Larsen og Bertel Haarder.]

Krab-Johansen, B., "Hvem kan spille på instrumentet". Kristeligt Dagblad 9.9. 1983. [Prædiken.]

Kvist, Vagn, "Grundtvigs mindedigt om sin moder blev til en fin og stærk opstandelsessalme". Vestkysten 20.8. 1983. [Om "Det livets ord".]

Kvist, Vagn, "Grundtvig var ikke selv tilfreds med 'Nu falmer skoven ...'". Vestkysten 10.9. 1983.

Kvist, Vagn, "'Det kimer nu ...' en fremragende optakt til julefesten". Vestkysten 24.12. 1983.

Kvist, Vagn, "'Privat' Grundtvig-salme med rigdom af sjæleføde". Vestkysten 28.1. 1984. [Om "Han, som har hjulpet hidindtil".]

Kvist, Vagn, "Middelalder-leise der forbinder påsken med julen«. Vestkysten 14.4. 1984.

Larsen, Arne G., "To uger i Askov med Grundtvig i centrum ". Jydske Tidende 29.1. 1983.

Larsen, Arne G., "Tanker 'dagen derpå’ efter en fødselsdag ". Jydske Tidende 16.9. 1983; Horsens Folkeblad 30.9. 1983.

Larsen, Ejvind, "Og riset vil jeg kysse". Information 16.5. 1983. [Et uddrag af den ovf. u. II anførte bog.]

Larsen, Ejvind, "Den ufærdige Grundtvig - som alle kender og ingen har læst til ende". Information 15.8. 1983.

Larsen, Ejvind, "Det tiltalende øjeblik som kalder på et svar. Kvinden og narcissisten Constance og Grundtvig". Information 17.8. 1983.

Larsen, Ejvind, "Det er, at vi vil være hinanden, som vi er". Information 22.8. 1983.

Larsen, Finn Stein, "Grundtvig og lyrikken". Weekendavisen 23.9. 1983.

Ledet, Frede, "Udblik over bøger i 200 året [...]". Aktuelt 23.6. 1983.

Lindhardt, P. G., "Grundtvigs bibelsyn". Kristeligt Dagblad 26.8. 1983.

Lindhardt, P. G., "Omkring Grundtvigs begravelse". Berlingske Tidende 11.9. 1983.

Lund, Grethe, "Vi ejer en skat inden i os selv". Jydske Tidende 25.9. 1983. 
Marquard, Grethe, "Hostrup og præstekonen fra Sejling til vennemøde med Grundtvig ". Midtjyllands Avis 24.9. 1983.

Meibom, Aksel, "Det grundtvigske". Vejle Amts Folkeblad 12.3. 1976.

Melchior, Arne, "Langt højere bjerge ...". Berlingske Tidende 1.6. 1980. [Kritik af Ebbe Kløvedal Reichs udlægning af sangen i en TV-udsendelse.]

Mortensen, Viggo, "Grundtvig i vore hjerter". Information 8.9. 1983. [Om en række Grundtvig-udgivelser.]

Myrdal, Jan, "Vejen fra Grundtvig og Brandes til Marx og Mao". Politiken 6.9. 1983.

Møllehave, Johannes, "Det ånder, det vifter, det lufter". Aktuelt 8.9. 1983.

Møllehave, Johannes, "Grundtvig her og nu". Fyns Amts Avis 7.9. 1983; Kolding Folkeblad 8.9. 1983; Morso Folkeblad 8.-9.9. 1983; Sjallands Tidende 8.9. 1983; Holstebro Dagblad 9.9. 1983; Midtjyllands Avis 9.9. 1983; Flensborg Avis 10.9. 1983; Herning Folkeblad 10.9. 1983; Vejle Amts Folkeblad 10.9. 1983; Nastved Tidende 19.9. 1983; Frederiksborg Amts Avis 27.11. 1983.

Nielsen, Erik A., "Salmens tonestige ". Kristeligt Dagblad 8.9. 1983.

Nielsen, Erling, "Livet her og nu". Dagbladet (Oslo) 8.9. 1983.

Nielsen, Johannes, "Grundtvig og Bibelen". Jydske Tidende 11.9. 1983.

Nielsen, Svend Aage, "Det hjemløse levende ord ". Dagbladet 27.8. 1983.

Nissen, Gunhild, "Oprør indefra". Berlingske Tidende 8.9. 1983.

Nørgaard, Bastholm, "Grundtvig - set fra bageste række". Vendsyssel Tidende 18.9. 1983.

Olafsson, Felix, "Grundtvigs plads i nordisk salmesang". Kristeligt Dagblad 21.5. 1983. [Om Grundtvig-salmer i islandsk oversættelse.]

Olafsson, Felix, "De skrev højstemte breve til hinanden". Frederiksborg Amts Avis 13.9. 1983. [Om Grundtvigs forhold til Chr. Molbech.]

Pedersen, Arne Fog, "Grundtvig foragtede sin tid i Århus. Åndløshed, terperi og dagdriveri prægede dagligdagen på Aarhus Katedralskole». Aarhuus Stiftstidende 25.4. 1983.

Pedersen, Arne Fog, "Også i dag har vi behov for en Grundtvig ". Flensborg Avis 3.10. 1983.

Perlt, Birger, "Fortid og fremtid - og det at være dansk". Frederiksborg Amts Avis 1.5. 1983.

Petersen, Peter, "Det mente Grundtvig slet ikke". Fyens Stiftstidende 12.12. 1980. [Indsigelse mod fejlcitering og misforståelse af Grundtvig.]

Petersen, Peter, "Frihed for alt, hvad der stammer fra ånd “. Frederiksborg Amts Avis 5.5. 1983; Flensborg Avis 30.5. 1983; Jydske Tidende 3.7. 1983; Vendsyssel Tidende 1. og 2.9. 1983.

Petersen, Peter, "Status over Grundtvig-året ". Jydske Tidende 19.1. 1984.

Reich, Ebbe Kløvedal, "Patriarken hyldes". Fyens Stiftstidende 8.9. 1983; Aalborg Stiftstidende 8.9. 1983; Aarhuus Stiftstidende 14.9. 1983.

Riis, Ricardt, "Grundtvig og George så ens på ejendomsret". Frederiksborg Amts Avis 24.9. 1983.

Rütz, Michael, "Englands frihed betog Grundtvig". Horsens Folkeblad 25.8. 1983; Kolding Folkeblad 30.8. 1983; Dagbladet 31.8. 1983; Flensborg Avis 3.9. 1983.

Rønnov, Børge, "Grundtvig er skam død, men mange vil stadig gerne hundse med ham ". Aalborg Stiftstidende 13.8. 1983.

Rønnov, Børge, "Det er digteren, vi takker". Aalborg Stiftstidende 8.9. 1983.

Sandvik, Sigurd, "Grundtvigs høgskuletanke". Bergens Tidende 9.9. 1983.

Schardelmann, Erik, "Der må være to digtere, der hedder Grundtvig ". Vendsyssel Tidende 19.12. 1983. [Om $" \mathrm{Nu}$ falmer skoven .... $]$ 
Schiøttz-Christensen, Aage, "Grundtvig contra Grundtvig". Berlingske Tidende 6.1. 1984.

Schouboe, Gunnar, "Druknede det i hurraråb?" Jydske Tidende 25.11. 1983.

Severinsen, Hanne, "Grundtvig - 80'ernes græsrod". Politiken 7.9. 1983.

Skjoldager, Emanuel, "Da 'det grundtvigske' blev til". Kristeligt Dagblad 8.9. 1983.

Skogemann, Pia, "Var Grundtvig shaman?» Information 10.8. 1983. [Debat: Flemming Tinggaard 15.8. 1983.]

Skov, Annagrethe, "De er i gæld til Grundtvig". Frederiksborg Amts Avis 11.9. 1983. [Samtale med Jindra Kulich og William M. Cave.]

Steen, Peter, "Grundtvigs kirkesyn". Midtjyllands Avis 10.9. 1983.

Storaas, Reidar, "Den utrulege Grundtvig". Bergens Tidende 6.9. 1983. [Om en af Erling Nielsen ledet ekskursion med syv norske kulturredaktører "i Grundtvigs fotefar "; cf. Paul Bjerke, Klassekampen 10.9. 1983, Marianne Gunnarsjaa, Arbeiderbladet 8.9. 1983, Hilde Haugsgjerd, Vårt Land 8.9. og 7.10. 1983, Simen Skjønsberg, Dagbladet 6. og 7.9. 1983.]

Sørensen, Svend Erik, "Grundtvig i Kerteminde. Da han kom for at lade sig vælge til Rigsdagen ". Morgenposten 19.6. 1983. [Efterfulgt af Grundtvigs egen beretning, oprindelig offentliggjort i Dannebrog 13.7. 1855, cf. Steen Johansen nr. 1120.]

Sørensen, Svend Erik, "Et ægteskabs tragedie". Fyens Stiftstidende 3.9. 1983.

Sørensen, Svend Erik, "Grundtvig selv ". Information 29.2. 1984. [Anmeldelse af en række Grundtvig-udgivelser.]

Sørensen, Villy, "Jesus er den sande Tor". Politiken 4.9. 1983. [Om "Nordens Mythologi ${ }^{\prime \prime}$.]

Teislev, Rich., "Hvad betyder folkelighed?" Jydske Tidende 1.2. 1983.

Teislev, Rich., "Frihedsbudskabet i Grundtvigsåret 1983“. Fyens Stiftstidende 2.3. 1983.

Teislev, Rich., "Nu forstår vi bedre Grundtvig". Amtsavisen Randers 27.9. 1983.

Terp, Christian Ulrich, "Sonate for gjallar-horn". Skive Folkeblad 3.9. 1983.

Thaning, Kaj, "Hele verdens Grundtvig". Morgenposten 4.9. 1983; Aalborg Stiftstidende 4.9. 1983; Aarhuus Stiftstidende 8.9. 1983.

Tiemroth, Peter, "Grundtvigs tanker bag højskolen i Østermarie“. Bornholmeren 9.9. 1983.

Tim, Jan Høgh, "Grundtvigs højskole er almen gyldig og aktuel". Ringkøbing Amts Dagblad 27.8. 1983.

Tim, Jan Høgh, "Grundtvig: En samlende og mægtig forkæmperånd for hele det kristne Europa ". Ringkobing Amts Dagblad 8.9. 1983.

Tjalve, Lars, "På studievisit hos den arbejdende Grundtvig". Kristeligt Dagblad 24.8. 1983.

Tjørnehøj, Henning, "Grundtvig og de underste klasser «. Information 10.9. 1983. [Hertil Niels Clemmensen, "Tjørnehøjs Grundtvig", 15.9. 1983.] [Let afvigende versioner: Frederiksborg Amts Avis 19.9. 1983; Horsens Folkeblad 28.9. 1983; Aalborg Stiftstidende 28.9. 1983.]

Toftdahl, Hellmut, "Før 1984". Jyllands-Posten 30.8. 1983.

Toftdahl, Lars, "Lys uden varme er helvedes kval ... "//Påskeblomst hvad vil du her?"/ "Den mageløse opdagelse [I-II] «. Bornholmeren 3.9., 10.9., 24.9. og 8.10. 1983.

Tolderlund-Hansen, G., "Tolerance - en afskyelig idé«. Kristeligt Dagblad 8.8. 1983.

Tornbjerg, Svend, "Grundtvig som politiker". Vestkysten 1.6. 1983; Flensborg Avis 2.6. 1983; Frederiksborg Amts Avis 4.6. 1983; Fyens Stiftstidende 13.7. 1983; Nastved Tidende 29.8. 1983. 
Uldum, Poul Erik, "Bestigningen af et vældigt bjerg". Midtjyllands Avis 12.1. 1983; Herning Folkeblad 1.6. 1983.

Wamberg, Niels Birger, "Skin lys gennem mørke". Politiken 11.9. 1983. [Om Ernst Triers møde med Grundtvig i havestuen på Store Tuborg.]

Watz, K. E., "Hvordan fortsætter vi danmarkshistorien på en ordentlig måde". LollandFalsters Folketidende 6.9. 1983. [Om en række Grundtvig-udgivelser.]

Wind, H. C., "Grundtvig og ny-grundtvigianismen". Weekendavisen 23.9. 1983.

Wivel, Henrik, "Grundtvigs mange ansigter". Kristeligt Dagblad 30.9. 1983.

Aarnes, Sigurd Aa., "Grundtvig og Norge». Bergens Tidende 8.9. 1983.

Lederartikler på 200-års fødselsdagen 8.9. 1983: Berlingske Tidende, Frederiksborg Amts Avis, Information, Kristeligt Dagblad, Sjallands Tidende, Vejle Amts Folkeblad.

Hyldestdigte på 200-års fødselsdagen 8.9. 1983: Jørgen Dilling Hansen, Sjallands Tidende; Johannes Møllehave, Politiken.

Grundtvig-tekster i dagspressen i forbindelse med 200-års fødselsdagen: "Grundtvigs egen beretning [om besøget i Kerteminde 1855]", Morgenposten 19.6. 1983; "En sød drøm [om højskoleliv i 1950'ernes Danmark] ", Politiken 2.9. 1983; "Høstprædiken [i Udby kirke 1812] “, Kristeligt Dagblad 8.9. 1983; "Fødselaren får ordet [uddrag af "Skolen for Livet «, 1838]", Jyllands-Posten 11.9. 1983.

\section{Varia}

Dag og Daad. N. F. S. Grundtvig i radio og tv. Danmarks Radio, København 1983. $16 \mathrm{s.}$ [Oversigt over "planlagte udsendelser ".]

Dansk Kirketidende CXXXV 1983, s. 277-300 (o: nr. 18, 19.8. 1983), markerede 200-året med en række tekster af Grundtvig. En række artikler om Grundtvig fortegnes separat, ligesom anmeldelser fortegnes i tilknytning til de anmeldte bøger. Grundtvig-relevante betragtninger indgår herudover i mange debatindlæg etc.

Dansk sangindeks 1980-81. Register til sange for born og voksne. Bibliotekscentralens Forlag, Ballerup 1982. Se personregistret s. 220-22.

Anmeldt af: Aage Jørgensen (Bogens Verden 1983, s. 180-81).

De levendes land. Tekst: N. F. S. Grundtvig. Musik: Erik Grip. ExLibris EXL 30.019. Gyldendal, København 1983. [LP-plade med følgende sange: „Velkommen i det grønne", "Oplysning ", "De levendes land ", "Den signede dag ", "Til bondefrihedens pris", "Nu skal det åbenbares", "Til min Asta" og "Nu falmer skoven".]

Eller, Povl (red.), Grundtvig og Danmark. Det nationalhistoriske Museum på Frederiksborg, Hillerød 1983. 110 s. [Udstillingskatalog med bidrag bl.a. af Margaretha BallePetersen, Svend Erik Bjerre, Lisbet Balslev Jørgensen, Hanne Loldrup og Torben Schousboe.] [Cf. Charlotte Christensen, "Grundtvig og Danmark ". Museumsmagasinet, nr. 25, december 1983, s. 3-4.]

Grundtvigs drom - en citatmosaik. Danmarks Radio, København 1983. 48 s. [Udgivet $\mathrm{i}$ tilknytning til en radio- og TV-udsendelsesserie.]

Horsner, John Wedell \& Henrik Fibiger Nørfelt (udg.), 69 melodier til Grundtvig-salmer $i$ Den danske Salmebog. Engstrøm \& Sødring, København 1983. $51 \mathrm{~s}$.

Anmeldt af: Henrik Glahn (Dansk Kirkemusiker Tidende LXXIX:12 1983, s. 19-22), 
Bengt Johnsson (Hymnologiske Meddelelser XII 1983 s. 274-77 [hvortil Jens Peter Larsen, "Hymnologiske Meddelelser, kirkemusikken og Vartov-sangen", smst. XIII 1984, s. 65-95]), Lasse Everlöf (Praesteforeningens Blad LXXIV 1984, s. 480-81).

Kjær, Gunnar, Grundtvigs 200 års fodselsdag. Ringe Fri- og Efterskole, Ringe 1983. 23 s. [Digt skrevet til Foreningen af frie Ungdoms- og Efterskoler's 25 års jubilæum i marts 1983.]

Kompendium: Grundtvigs syn på forsoningen. København 1983. (Arken-Tryk, nr. 34.) [Indhold: Stig Bang-Jensen, "Forsoningslæren hos Grundtvig", s. 1-36 + 1-8; Grete Bøje, "Grundtvigs forsoningslære på baggrund af udvalgte afsnit af 'Den Christelige Børnelærdom' og udvalgte salmer", s. 1-24 + 1-2; Eva Melhof, "Forsoningslæren hos Grundtvig belyst ud fra 'Den Christelige Børnelærdom' og 'Sangværket' ", s. 1-3 + 131.]

Larsen, Ejvind \& Ebbe Kløvedal Reich, Hjertets søde morgendrom eller Til kamp mod dødbideriet. Rosinante, Charlottenlund 1983. $115 \mathrm{~s}$. [Revideret version af skuespil fra 1974; Bådteatrets opførelse anmeldt af: Knud Cornelius (Frederiksborg Amts Avis 10.9. 1983), Flemming Everfelt (Vestkysten 15.9. 1983), Tom Felsen (Vendsyssel Tidende 21.9. 1983), Mogens Garde (B.T. 10.9. 1983), Jørgen Gleerup (Fyens Stiftstidende 10.9. 1983), Anne Chaplin Hansen (Jyllands-Posten 10.9. 1983), Birthe Johansen (Roskilde Tidende 20.9. 1983), Henrik Neiiendam (Weekendavisen 16.9. 1983), Kjerstin Norén (Information 10.9. 1983), Elin Rask (Kristeligt Dagblad 10.9. 1983).]

Litteraturtolkninger 1979. Bibliotekscentralen, Ballerup 1980. S. 105-09. [Fortegnelse over tolkninger af Grundtvig-tekster.]

Litteraturtolkninger 1980-83. Bibliotekscentralen, Ballerup 1983 [på omslaget: 1984]. S. 84-93. [Fortegnelse over tolkninger af Grundtvig-tekster.]

N. F. S. Grundtvig 1783-1872. 18 salmer og sange. Sunget af: KFUM's Sangere og Erik Harbo. Dirigent: Jørgen Berg. Danica DLP 8037, 1983. [LP-plade med følgende sange: "Den signede dag", "Guds menighed, syng", "Hil dig frelser og forsoner", "Som forårssolen morgenrød", "Påskeblomst! Hvad vil du her ", "I al sin glans nu stråler solen", "Nu falmer skoven", "Kirken den er et gammelt hus", "Kirkeklokke! Ej til hovedstæder", "Moders navn er en himmelsk lyd", "Jeg gik mig ud en sommerdag", "Der er et land så kosteligt", "Om Dannemarks kvide der lød en sang", "Kommer hid, I piger små ", "Det var en sommermorgen", "Nu skal det åbenbares", "Jeg gik mig i marken" og "Et jæunt og muntert, virksomt liv på jord ".]

Anmeldt af: John Wedell Horsner (Organist-bladet IL 1983, s. 454-57).

Nordtext, udgivet af Nordisk Institut ved Aarhus Universitet, 13. årg., nr. 2, juni 1984: "Specialeoversigt 1982-1983". [Heri fortegnes ét Grundtvig-speciale: Søren Kjærsgaard Mortensen, "Naturalister med ånd. En Grundtvig-studie", 1982.]

Ordet som det lyder. Unge Akademikeres Kor, dirigeret af Søren K. Hansen. Edition Egtved EGTLP 10, 1983. [LP-plade med følgende sange: "Lovsynger Herren", "Sov sødt, barnlille", "Kirken den er et gammelt hus ", "Det er så yndigt at følges ad ", * "De levendes land ", "At sige verden ret farvel ", * Morgenhanen atter gol ", "Udrundne er de gamle dage", "Et jævnt og muntert, virksomt liv på jord ", "Langt højere bjerge", "Jeg gik mig ud en sommerdag", „ "Ordet var fra Arilds-Tid", "Moders navn" og "Skyerne gråne«; de med * mærkede har nyskrevne melodier af hhv. Otto Mortensen, Svend S. Schultz og Per Nørgård.]

Prasteforeningens Blad LXXIII 1983, s. 569-75 ("Uddrag af to Grundtvig-prædikener"), 585-89 ("Langfredag 1832. Prædiken af N. F. S. Grundtvig "). 
Påskeliljen - et Grundtvig-program. Drama, Gråsten 1983. 60 s. [Programmet, udarbejdet af Sønderjysk Forsøgsscenes kirkespilgruppe, omfatter: 1. del, Uffe Bjerre, "Om Grundtvig " (salmer, recitationer etc. i fortællingsramme); 2. del, "Grundtvigs Påskeliljen ", bearbejdet af Arne Aabenhus; 3. del, Bente List Svendsen, "Musik til Påskeliljen «.] [Cf. Uffe Bjerre, "Grundtvig - 200 året - Påskeliljen". I: Karsten Biering, m. fl. (red.), Amatorteater - folkekultur. Festskrift til Arne Aabenhus 18.10. 1983. Drama, Gråsten 1983. S. 124-25.]

Reich, Ebbe Kløvedal, N. F. S. Grundtvig. Bibliotekscentralen, Ballerup 1983. 8 s. [Forfatterportræt.]

Samlerens antologi af nordisk litteratur, V: Perioden 1785-1825. Redigeret af Finn Hauberg Mortensen og Per Olsen. Samlerens Forlag, København 1983. Indledningen s. 67-70, samt tekstudvalget s. 193-99, 258-59 og 265-72.

Schroeder, Carol L., A Bibliography of Danish Literature in English Translation 1950-1980. With a Selection of Books about Denmark. Det danske Selskab, Copenhagen 1982. S. 6670.

Slumstrup, Finn, Factsheet Denmark/N. F. S. Grundtvig. Translated by Anne Born. Royal Danish Ministry of Foreign Affairs, Copenhagen 1983. 8 s. [Også på fransk, spansk og tysk.]

Sogen efter midten. Redigeret af Knud Bjarne Gjesing. Forlaget Systime, Herning 1983. Indledningen s. 27-28, samt tekstudvalget s. 59-60, 65 og 87-88. (Systimes periodeserie, 1760-1830.)

Soren Kierkegaards Papirer. 2. forøgede udgave ved Niels Thulstrup. XV: Index G-Q. Ved N. J. Cappelørn. Gyldendal, København 1976. S. 40-43. [Henvisninger til samtlige Kierkegaards Grundtvig-ytringer i Papirerne.]

Thaning, Kaj, "Götz Harbsmeier 1910-1979 «. Grundtvig-Studier 1979, s. 7-9. [Nekrolog.] Thysen, Hans S., "Grundtvig og Sønderjylland “. Haderslev Stiftsbog 1983, s. 18-33. [Om de grundtvigske tankers betydning for det folkelige og kirkelige liv i landsdelen.] 